\title{
Multiproxy reconstruction of the palaeoclimate and palaeoenvironment of the Middle Miocene Somosaguas site (Madrid, Spain) using herbivore dental enamel
}

\author{
Laura Domingo a,*, Jaime Cuevas-González ${ }^{\text {b }}$, Stephen T. Grimes ${ }^{c}$, Manuel Hernández Fernández a,d, \\ Nieves López-Martínez ${ }^{\text {a }}$ \\ a Dept. Paleontología. Facultad CC. Geológicas, Universidad Complutense de Madrid, 28040 Madrid, Spain \\ ${ }^{b}$ Dept. Ciencias de ia Tierra y del Medio Ambiente, Laboratorio de Petrología Aplicada, Universidad de Alicante, 03690 Alicante, Spain \\ ' School of Eurth, ccean and Environmental Sciences, University of Plymouth, Drake Circus, PLA 8AA Plymouth, Devon, United Kingdom \\ a Unidad de Investigación de Paleontología, Instituto de Geología Económica, Consejo Superior de Investigaciones Científicas, 28040 Madrid, Spain
}

Keywords:

Somosaguas

Large mammalian herbivores

Oxygen and carbon isotopes

Trace elements

Middle Miocene

South-Western Europe

\begin{abstract}
A B S T R A C T
Profound palaeoclimatic changes took place during the Middle Miocene. The Miocene Climatic Optimum ( 20 to $14-13.5 \mathrm{Ma}$ ) was followed by a sudden ( $200 \mathrm{ka}$ ) decrease in temperature and an increase in aridity around the world as a consequence of the reestablishment of the ice cap in Antarctica. Somosaguas palaeontological site (Madrid Basin, Spain) has provided a rich record of mammal remains coincident with this global event (Middle Miocene Biozone E, 14.1-13.8 Ma). It contains four fossiliferous levels (T1, T3-1, T3-2 and T3-3, with T1 being the oldest) that span an estimated time of $\sim 105-125 \mathrm{ka}$. Scanning Electron Microscope (SEM) and Rare Earth Element (REE) analyses performed on herbivore tooth enamel (Gomphotherium angustidens, Anchitherium cf. A. cursor, Conohyus simorrensis, Prosantorhinus douvillei and ruminants) indicate that diagenetic processes have not been intense enough as to obscure the original geochemical signal. Stable isotope $\left(\delta^{18} \mathrm{O}_{\mathrm{CO} 3}, \delta^{13} \mathrm{C}_{\mathrm{CO} 3}\right.$ and $\left.\delta^{18} \mathrm{O}_{\mathrm{PO} 4}\right)$ analyses have been measured on the herbivore tooth enamel across these levels with the aim of determining to what extent the global cooling and aridity pattern is recorded at this site. A decrease in $\delta^{18} \mathrm{O}_{\mathrm{CO} 3}$ and $8^{18} \mathrm{O}_{\mathrm{PO}}$ has been detected from T1 to T3-3 and T3-1 to T3-3 respectively indicating a progressive drop of about $6^{\circ} \mathrm{C}$ (from around $18^{\circ} \mathrm{C}$ to $12^{\circ} \mathrm{C}$ ) in mean annual temperatures within T3. Tooth enamel $8^{13} \mathrm{C}$ values experience an increase from T3-1 to T3-3 suggesting an increase in aridity. $\mathrm{Ba} / \mathrm{Ca}$ analyses have also been performed on the tooth enamel in order to detect changes in the palaeoecology of the studied taxa. This ratio allows the establishment of particular feeding patterns such as a more browsing habit in the case of Gomphotherium angustidens compared to Anchitherium cf. $A$. cursor as suggested by higher $\mathrm{Ba} / \mathrm{Ca}$ values in the latter. Trace elements do not support any significant change across the succession in the dietary behaviour of the species analyzed, despite the stable isotopes evidence of an important palaeoclimatic shift from T1 to T3-3.
\end{abstract}

\section{Introduction}

The Lower and Middle Miocene witnessed remarkable global changes in palaeoclimatic and palaeoenvironmental conditions (Zachos et al., 2001; Böhme, 2003). The Miocene Climatic Optimum ( 20 to 14-13.5 Ma), a warm and humid subtropical period, was followed by a quick cooling episode and an increase in the aridity patterns linked to the reestablishment of the Antarctica ice cap during the Middle Miocene. This event has been recorded in marine and continental sections throughout the world highlighting its global magnitude (Kennett and Barker, 1990; Frakes et al., 1994; Böhme, 2003; Shevenell et al., 2004; Lewis et al., 2008; Costeur and Legendre, 2008). Even though uncertainty concerning the ultimate cause that brought about these profound changes in the global climate still

\footnotetext{
* Corresponding author. Tel.: +34 913944875; fax: +34913944849.

E-mail address: lauradomingo@geo.ucm.es (L. Domingo).
}

remains, several hypotheses have been invoked as trigger mechanisms. These include a decrease in global atmospheric $\mathrm{pCO}_{2}$ levels (Kürschner et al., 2008), and also tectonic factors including the uplift of the Himalaya, which gave rise to profound changes in the atmospheric circulation pattern resulting in an increase in the seasonality of the precipitation and in aridity levels in mid and high latitude regions in the Northern Hemisphere (Pagani et al., 1999; Wang et al., 2006).

The Madrid Basin is a suitable region to check how these climatic shifts influenced the palaeoecology of the mammalian faunas. The majority of the palaeontological mammal record of this basin belongs to the Aragonian continental stage as defined by Daams et al. (1977) which spans an age range of between $\sim 17 \mathrm{Ma}$ and $\sim 11 \mathrm{Ma}$. Particularly, the Somosaguas site was dated by Luis and Hernando (2000) around 14.1 to $13.8 \mathrm{Ma}$ (Biozone E, Late Middle Aragonian, calibrated by Daams et al., 1999) on the basis of the micro-mammals discovered in Somosaguas. These dates coincide with the decrease in 
the temperature and the increase in the aridity happened just after the Mid-Miocene Climatic Optimum. Somosaguas site is situated in the Campus of the Universidad Complutense de Madrid in Pozuelo de Alarcón (Madrid, Spain). It has been systematically excavated since 1998 and up to now, two superposed sites have been excavated: North Somosaguas (represented mainly by macro-mammal remains) and South Somosaguas (represented mainly by micro-mammal remains). To date, a total of 29 vertebrate species, 24 of which are mammals, have been found (López-Martínez et al., 2000; Hernández Fernández et al., 2006). In this study, tooth enamel from a range of mammals recorded in the Somosaguas site has been analyzed for stable isotopes $\left(\delta^{18} \mathrm{O}_{\mathrm{C} \bullet 3}, \delta^{13} \mathrm{C}_{\mathrm{C} \bullet 3}\right.$ and $\left.\delta^{18} \mathrm{O}_{\mathrm{P} \bullet 4}\right)$ and $\mathrm{Ba} / \mathrm{Ca}$ ratios.

Oxygen isotopes from tooth enamel have been widely used to determine palaeotemperatures and the evolution of past climates (Longinelli, 1984; Kolodny and Raab, 1988; Ayliffe et al., 1992; Lécuyer et al., 1996, 2003a; Grimes et al., 2003, 2005). The $\delta^{18} \mathrm{O}$ value in both enamel phosphate and carbonate is related to that of body water, which in turn records water uptake (inspired $\mathrm{O}_{2}$, drinking water and plant water) and loss (excretion, expired $\mathrm{CO}_{2}$ and water vapour) of the animal during tooth development (Bryant and Froelich, 1995; Kohn, 1996). $\delta^{18} \mathrm{O}$ values can be interpreted as changes in the isotopic composition of meteoric water, which are in turn positively correlated to mean annual temperature and humidity. Thus, an increase in temperature and aridity is associated with an enrichment of the heavy isotope $\left({ }^{18} \mathrm{O}\right)$ whereas, a decrease in temperature and an increase in humidity result in a depletion of the heavy isotope (Luz et al., 1990; Ayliffe et al., 1992). $\delta^{18} \mathrm{O}$ values from herbivore tooth enamel may also provide information about the type of diet and the evaporative rate suffered by the consumed vegetation and hence, it is possible to differentiate between obligate drinkers (animals that obtain most of their water from drinking, frequently grazers feeding on vegetation with heavier isotopic values due to higher evaporation) and nonobligate drinkers (those obtaining water mainly from plants, frequently browsers feeding on vegetation with lighter isotopic values) (Kohn, 1996; Levin et al., 2006). The $\delta^{18} \mathrm{O}$ value of tooth enamel may also be affected by other factors such as the relative proximity to the coast, orography and latitude. During the Middle Miocene, Somosaguas was situated in the interior of a continental landmass far from the coast. It was also more than $30 \mathrm{~km}$ away from any known mountain chains, and itwas situated ata middle latitude $\left(\sim 40^{\circ} \mathrm{N}\right)$. Therefore, the $\delta^{18} \mathrm{O}$ value of tooth enamel from Somosaguas was probably not influenced by these non temperature related factors.

Traditionally, the carbon isotopic composition from the enamel of herbivore mammals has been used to distinguish between different types of palaeodiets as it faithfully records the isotopic composition of the plants they eat (Quade et al., 1992, 1995; Latorre et al., 1997; Fox and Fisher, 2004; Grimes et al., 2004). Plants can be grouped into three different photosynthetic pathways: $\mathrm{C}_{3}, \mathrm{C}_{4}$ and $\mathrm{CAM}$ (Crassulacean Acid Metabolism). $C_{3}$ plants use the Calvin photosynthetic pathway and account for $85 \%$ of the terrestrial plants (Ehleringer et al., 1991). They include trees, shrubs, forbs, and cool-season grasses. $\mathrm{C}_{4}$ plants use the Hatch-Slack photosynthetic pathway and account for $5-10 \%$ of the terrestrial plants (Ehleringer et al., 1991). They are mainly tropical, warm-season sedges and grasses. Finally, CAM plants are represented

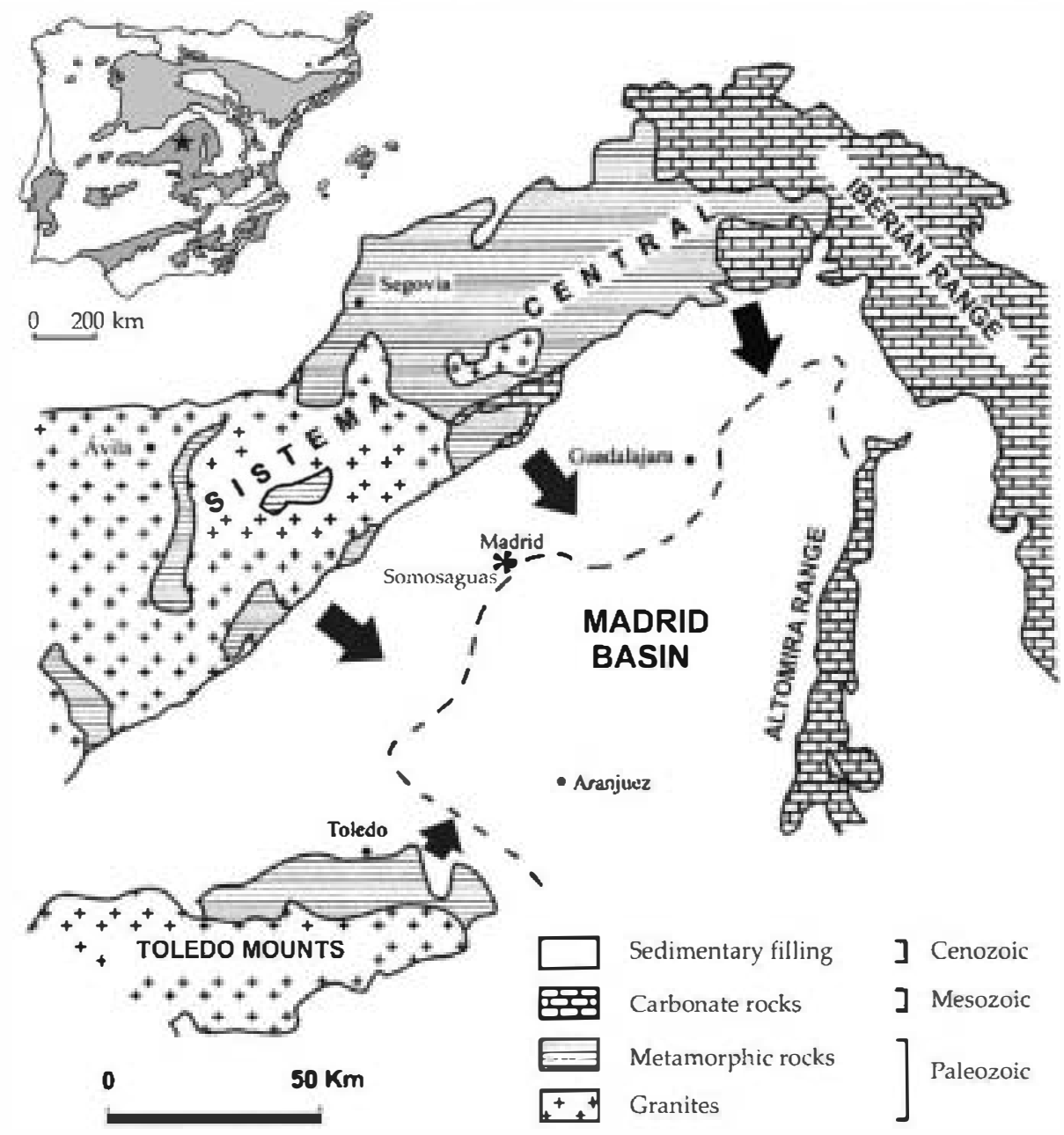

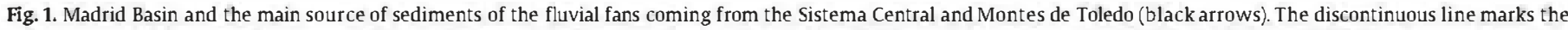

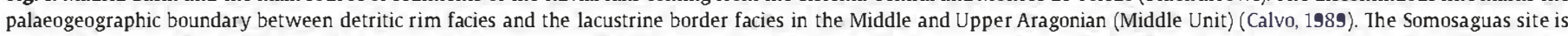

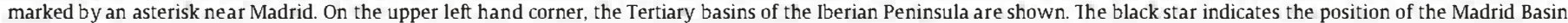


by the succulents (O'Leary, 1988; Ehleringer et al., 1991). $C_{3}$ plants discriminate more against the heavy isotope $\left({ }^{13} \mathrm{C}\right)$ during photosynthetic fixation of $\mathrm{CO}_{2}$ compared to $\mathrm{C}_{4}$ plants. This results in very different carbon isotope compositions between these two kinds of photosynthetic pathways. ${ }^{13} \mathrm{C}$ values of $C_{3}$ plants range from $-34 \%$ to $-23 \%$ (VPDB), with an average of $-27 \%$ (VPDB), whereas $C_{4}$ plants have ${ }^{13} \mathrm{C}$ values ranging from $-17 \%$ o to $-9 \%$ (VPDB), with an average of -13\%(VPDB) (Bender, 1971; Farquhar et al., 1989). CAM plants are able to fix carbon by using both types of photosynthetic pathways and as a result, they show intermediate carbon isotopic values. However, CAM plants are not particularly important when trying to distinguish among different types of palaeodiets as they do not constitute an important food source for herbivore mammals (Quade et al., 1994; MacFadden et al., 1994, 1996). Cerling and Harris (1999) determined an enrichment in ${ }^{13} \mathrm{C}$ between diet and tooth enamel of $14.1 \pm 0.5 \%$ such that tooth enamel from herbivores feeding on $C_{3}$ vegetation have $\delta^{13} \mathrm{C}$ values of between $-16 \%$ and $-9 \%$ (VPDB), whereas those eating $\mathrm{C}_{4}$ grasses have $\delta^{13} \mathrm{C}$ values of between $-1 \%$ and $+3 \%$ 。(VPDB).

The use of trace elements in the palaeoecological reconstruction of mammals has been widely developed during the last few decades (Sillen, 1986, 1992; Gilbert et al., 1994; Safont et al., 1998; Sponheimer et al., 2005; Sponheimer and Lee-Thorp, 2006) and particularly, with the aim of distinguishing between different types of diet (Balter et al., 2002; Palmqvist et al., 2003; Sponheimer et al., 2005; Sponheimer and Lee-Thorp, 2006). Such is the case of barium (Gilbert et al., 1994; Safont et al., 1998) based on the premise that mammals discriminate against this element (biopurification of calcium). This process gives rise to $\mathrm{Ba} / \mathrm{Ca}$ ratios decreasing up the food chain (Elias et al., 1982; Burton et al., 1999; Blum et al., 2000). Most of studies of mammalian palaeofaunas have focused on post-Late Miocene communities after the expansion of the $C_{4}$ plants had occurred (e.g. Sillen, 1986, 1992; Gilbert et al., 1994; Safont et al., 1998; Palmqvist et al., 2003;
Sponheimer et al., 2005; Sponheimer and Lee-Thorp, 2006). However, Somosaguas is a Middle Miocene palaeontological site ( $14.1-$ $13.8 \mathrm{Ma}$ ) and therefore, the objective of this study is not to detect a $\mathrm{C}_{3}-\mathrm{C}_{4}$ diet change, but rather to determine whether there is any change in the pattem of the trace elements among the different stratigraphic levels and to detect differences among the taxa that could indicate a change in the grazing-browsing gradient of feeding behaviour.

\section{Geological setting}

The Somosaguas palaeontological site is located in the Madrid Basin, which forms part of one of the main Cenozoic basins in the Iberian Peninsula, the Tagus Basin (Fig. 1). During the Miocene, the Madrid Basin was mainly filled by continental arkosic, clayish and evaporitic sediments deposited by alluvial fans and lakes whose source area was mainly situated in the Sistema Central (Fig. 1). Megías et al. (1980), Alberdi et al. (1985) and Calvo et al. (1993) proposed three different depositional units for these sediments according to tectonic, stratigraphic and sedimentological criteria: the Lower Unit (Ramblian-Middle Aragonian, 20 to $15 \mathrm{Ma}$ ), the Middle Unit (Middle Aragonian-Vallesian, $\sim 15$ to $10 \mathrm{Ma}$ ) and the Upper Unit (VallesianTurolian, $\sim 10$ to $5.3 \mathrm{Ma}$ ). The Somosaguas section belongs to the Middle Unit.

Three different stratigraphic levels have been recognized in Somosaguas: T1, T2 and T3 (from the bottom to the top). The T2 level pinches out to the north, so that T3 lies directly over T1 at North Somosaguas (Fig. 2). Mínguez-Gandú (2000) gave the following sedimentological description of these three levels:

- T1: Brown-yellowish arkosic level with clay content increasing towards the top of the layer, which has been interpreted as mud

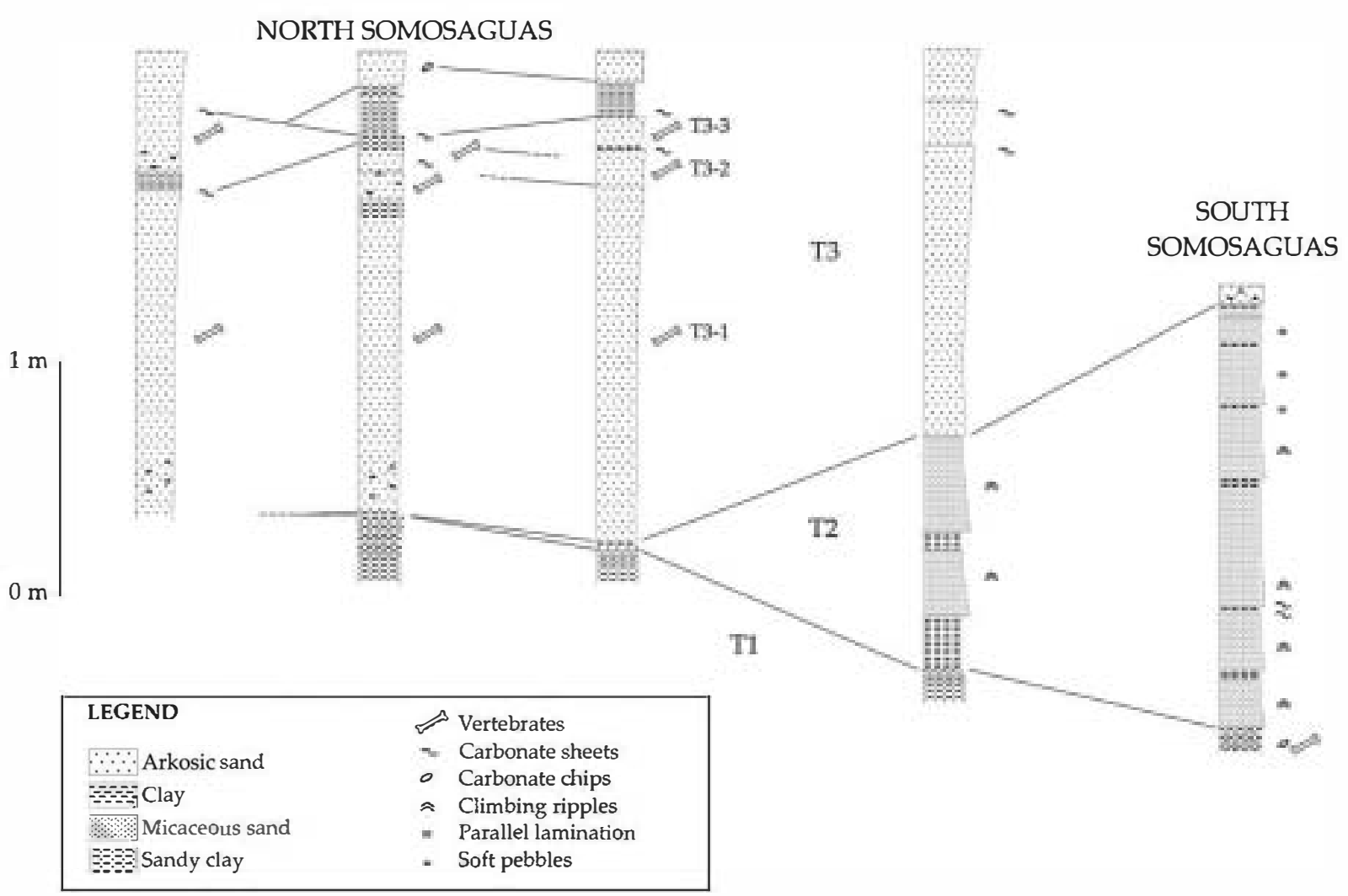

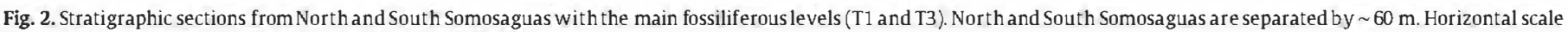
is not maintained. Modified from Cuevas-González (2006). 
flow sediments. South Somosaguas outcrops in these sediments where mostly micro-mammal remains have been found.

- T2: Alternation of clean micaceous sands and brown clays. Only a few fossils have been observed in this level that has been interpreted as produced by deposit of suspended load after the deceleration of a stream reaching its base level in a pond.

- T3: Brown-yellowish arkosic sandy and conglomeratic level with a clayish matrix, interpreted as a debris-flow. North Somosaguas, where mostly macro-mammal remains are found, outcrops here.

In summary, T1 and T3 represent middle-distal alluvial fan facies, whereas $\mathrm{T} 2$ corresponds to a distal facies of those fans represented by sub-aquatic environments in a permanent lake shore or pond (Mínguez-Gandú, 2000; Cuevas-González, 2005).

Elez (2005) carried out a Geographic Information System (GIS) reconstruction of the layout of the fossil remains from the beginning of the excavation in 1998. This author discovered that the concentration of fossil remains in T3 level was distributed in 3 distinct zones, namely T3-1, T3-2 and T3-3 from the bottom to the top, separated by two levels with an apparent shortage of fossils. The morphology of these levels, concaving upwards and rapidly pinching out towards the South, indicates the existence of multiple avalanche episodes (Elez, 2005).

Recently, Montes et al. (2006) carried out a magnetostratigraphic study in the Madrid Basin with the aim of proposing a reliable geochronological calibration of the geological record in this area. The sedimentation rate estimated by these authors for two of the three depositional units defined in the Madrid Basin (Lower Unit and Middle Unit) was $\sim 4.0-4.7 \mathrm{~cm} / \mathrm{ka}$. The Somosaguas site mammalian sequence shows a thickness of $\sim 5 \mathrm{~m}$. According to these results, a time-span of 105-125 ka can be estimated for the $\sim 5$ m-thick Somosaguas succession between the $\mathrm{T} 1$ and T3-3 levels.

\section{Previous palaeoclimatological interpretations}

The mammalian fossil remains from the Aragonian discovered in the Madrid Basin are characteristic of a faunal association indicative of a tropical climate, with slight variations triggered by changes in temperature and humidity (Amezua et al., 2000; Hernández Fernández et al., 2003, 2006).

There have been different approaches for the reconstruction of the Aragonian continental palaeoclimate in the Iberian region. Van der Meulen and Daams (1992) proposed for the neighbouring Calatayud-
Daroca Basin a relative humidity curve based upon quantitative and qualitative multivariate analyses of the sequence of 59 rodent assemblages from Lower to Middle Miocene continental deposits. On the other hand, Fraile et al. (2000) proposed for the Madrid Basin a humidity curve based on the mammal assemblages. In both studies, it is noticeable that an increase in the degree of aridity in the Lower Aragonian is proposed, so that during the Middle Aragonian a maximum dry period is reached (Fig. 3). After that, both studies agree that an increase in the relative humidity occurred during the Upper Aragonian. The most significant difference between both studies lies in the position of the aridity peak. According to van der Meulen and Daams (1992), the driest period would coincide with Biozone E whereas Fraile et al. (2000) placed this event in Biozone D (Fig. 3).

On the basis of the micromammal association found in Somosaguas, Luis and Hernando (2000) observed a predominance of termophile and/or xerophile open land species such as Democricetodon (=Fahlbuschia), Armantomys, Heteroxerus and Lagopsis. Luis and Hernando (2000) also argued that an environment similar to that existing nowadays in the tropical or subtropical savannah must have existed in Somosaguas. Although the shortage of permanent freshwater bodies in the whole region can be argued, since no evidence of fish, amphibian or crocodile remains has yet been detected in the Madrid Basin, Luis and Hernando (2000) did not exclude the existence of humid soil in the Somosaguas area, due to the presence of anguid lizards.

Hernández Fernández et al. (2003) carried out a palaeoclimatic study of the assemblages of large mammalian herbivores from the Ramblian to the Vallesian ( 20-10 Ma). Based on the changes in the community structure of these faunas, they argued that in the initial phases of this period (from Biozone $\mathbf{Z}$ to Biozone Dc) there existed mainly sites without any evidence of a dry season or with only a moderately dry season. However, from the Biozone Dd onwards, the sites with evidence of an extended drought prevail. Somosaguas would pertain to this period. Subsequently, in the Vallesian, sites without or with a moderate dry season appear again. Finally, a later analysis based upon the proportion of species representative of arid environments in the rodent faunas from the Madrid Basin including the Somosaguas site (Hernández Fernández et al., 2006) evidenced an alternation of two arid phases in biozones DC and E, separated by a relatively humid period in biozone Dd (Fig. 3).

Interestingly enough, the hypothesis of an increase in the aridity can also be detected from a sedimentological point of view. Cuevas-

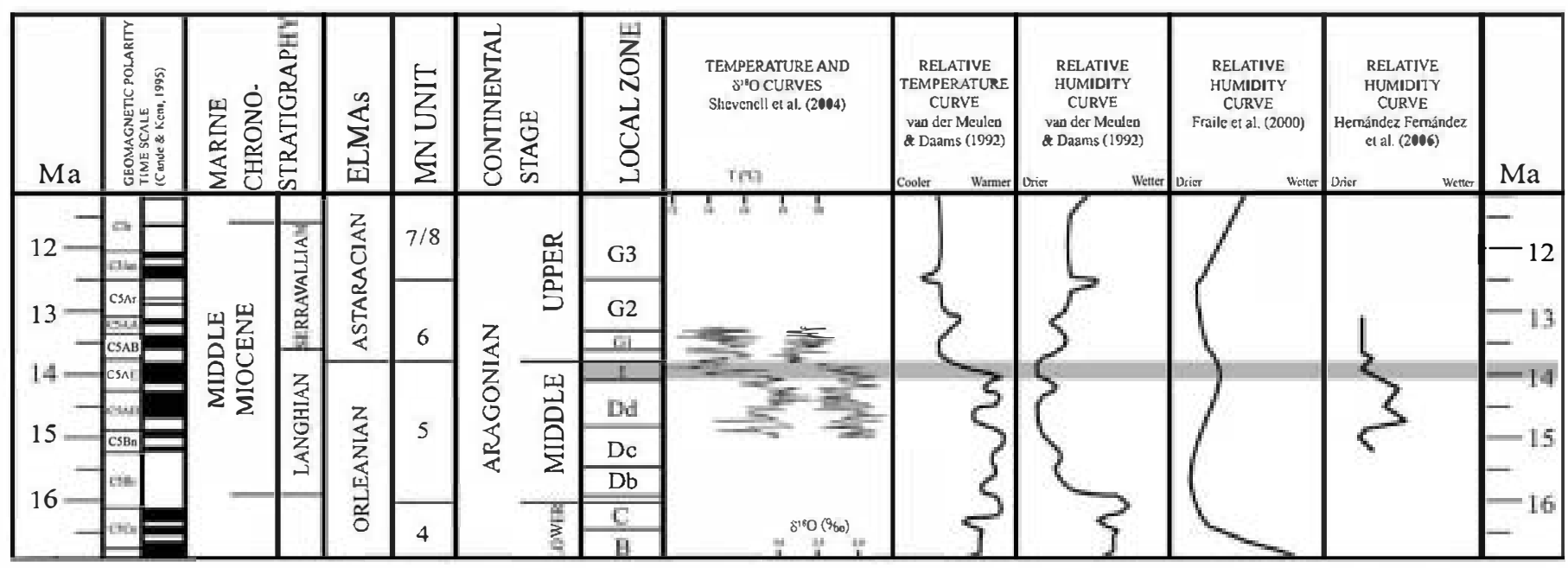

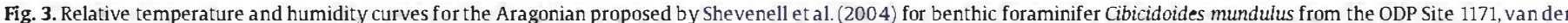

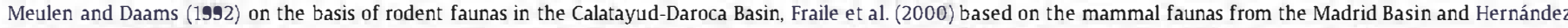

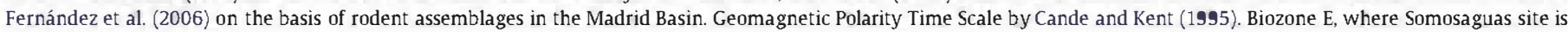
situated, appears in grey. 
González (2005) proposed that large arkosic mass-flow alluvial fans from the Madrid Basin might have been formed under an intense arid climate with intense seasonal rain, as the mass transport stands out against the almost-absent fluvial facies. More recently, Carrasco et al. (2008) proposed that the predominance of smectite (70\%) in the clay mineral assemblage from Somosaguas is suggestive of a subtropical climate with an alternation of long dry periods and short wet periods. According to them, the clays associated with the incipient caliche soils in the Somosaguas site may also be indicative of semiarid conditions with precipitation values of $\sim 100-500 \mathrm{~mm} /$ year.

Other regional studies have also suggested an arid to semi-arid climate. For example, Jiménez-Moreno and Suc (2007) carried out a palynological analysis from different areas in Europe ranging from the Langhian to the Serravallian (Middle Miocene). They stated that during this period the pollen assemblages in Spain were typical of arid environments (including Neurada, Lygeum, Prosopis, Calligonum, Nitraria, Caesalpiniaceae, etc.), and suggest dry conditions in a subtropical climate with a marked seasonality.

Finally, van der Meulen and Daams (1992) attribute the inversion of the relationship between temperature and humidity curves to a major change of the climatic belts in the late Early Miocene. The observed shift (an increase in aridity followed by a decrease in temperature), interpreted from the mammal record in the Middle Miocene, may be related to the positive $\delta^{18} \mathrm{O}$ change detected by Kennett and Barker (1990) and Shevenell et al. (2004; Fig. 3) in the Middle Miocene marine record. According to Sarnthein et al. (1982), the climatic deterioration in the late Early Miocene resulted in widespread continental aridity as evidenced by enhanced aeolomarine dust deposition off the Northwest African coast.

\section{Materials and methods}

On account of the shortage and value of the carnivore remains at this site (Salesa and Morales, 2000), only the dental enamel of the herbivores has been analyzed. Both, gomphothere Gomphotherium angustidens and equid Anchitherium cf. A. cursor are considered browsing species, although the latter was likely better adapted to open grasslands according to its postcranial morphology (Sánchez et al., 1998; Salesa and Sánchez, 2000; Hemández Fernández et al., 2003). Conohyus simorrensis is a suid that may have had an omnivorous diet as deduced from its dentition with hypertrophid premolars, bunodont molars with well-developed pyramidal cuspids and hyaenoid-type teeth (Sánchez, 2000; van der Made and Salesa, 2004). Prosantorhinus douvillei is characterized by brachydont teeth, hippopotamid appearance and extreme brachypody (Cerdeño, 1989). In Somosaguas, there exist three different ruminant genera (Sánchez, 2000): Heteroprox, Tethytragus and Micromeryx. Due to the shortage of material and to the fact that only small fragments of ruminant teeth were sampled for geochemical analyses, it was not possible to assign every ruminant tooth to a specific genus. Therefore, from now onwards we will put these three genera under the same group: "ruminants".

The enamel of Gomphotherium angustidens, Anchitherium cf. A. cursor, Conohyus simorrensis, Prosantorhinus douvillei and ruminants was analyzed for F, P and Ca concentrations, Rare Earth Elements (REEs) ratios, stable isotopes $\left(\delta^{18} \mathrm{O}_{\mathrm{C} \bullet 3},{ }^{13} \mathrm{C}_{\mathrm{C} \bullet 3}\right.$ and $\left.{ }^{18} \mathrm{O}_{\mathrm{P} \bullet 4}\right)$ and $\mathrm{Ba} / \mathrm{Ca}$ ratios.

Cuevas-González (2006) carried out a preliminary isotopic study of the Somosaguas mammal enamel and paleosoil carbonate. This author analyzed enamel samples from T1 (South Somosaguas) and T3 (North Somosaguas), which was divided into upper and lower levels. In the present study, the number of enamel samples analyzed has been substantially increased and samples from the three levels in T3 (T3-1, T3-2 and T3-3) proposed by Elez (2005) have been included. CuevasGonzález (2006)'s lower T3 would correspond to T3-1 and T3-2, whereas his upper T3 is equivalent to our T3-3.

Using the method described in Grimes etal. (2003), analyses of Ca, P and $\mathrm{F}$ contents were performed on the Scanning Electron Microscope in order to check the mineralogy of the enamel. A JSM-6400 Scanning Electron Microscope at the C.A.I. Microscopia Electrónica of the Universidad Complutense de Madrid (Spain) was used.

Analyse of the REEs (La, Ce, Pr, Nd, Sm, Eu, Gd, Tb, Dy, Ho, Er, Yb, Lu) were performed to check the degree of diagenetic alteration of the mammal enamel. $\mathrm{Ba} / \mathrm{Ca}$ ratios were also analyzed on the tooth enamel samples in order to detect differences in the dietary behaviour. In both cases, samples were acid digested by adding $1 \mathrm{ml}$ of $4 \mathrm{M}$ nitric acid for $\sim 1 \mathrm{~h}$, diluted in ultrapure water and analyzed on a PlasmaQuad PQ2+ Turbo inductively coupled plasma source mass spectrometer (ICP-MS) at the University of Plymouth (United Kingdom). The precision of this instrument is better than $2-4 \%$. Each standard and sample was analyzed with three replicate scans. The average value of these three measurements was used to determine a final mean value. In the case of REEs analyses, the ICP-MS was calibrated using three linearity standards at the following REEs levels: 4, 8 and $32 \mathrm{ppb}$. The laboratory standard P/N 4400-130373 from the University of Plymouth (United Kingdom) was also used during the analyses. The concentrations of REEs are plotted relative to an intemational standard. PAAS values (PostArchean Australian Shale of Taylor and McLennan, 1985) were used to normalize the raw REE data in this study. For $\mathrm{Ba}$, the standard used was Bone Ash 1400, with a standard Ba value proposed by Balter and Lécuyer (2004). Ba/Ca values are presented as ratio $\times 1000$ (Sillen, 1992; Balter et al., 2002, Palmqvist et al., 2003; Sponheimer and Lee-Thorp, 2006). The Ca content was analyzed by using atomic absorption spectrometry (AAS) on a Varian Spectr AA at the University of Plymouth (United Kingdom).

73 samples have been analyzed for ${ }^{18} \mathrm{O}_{\mathrm{C} \bullet 3}$ and $\delta^{13} \mathrm{C}_{\mathrm{C}}$ and 51 for $\delta^{18} \mathrm{O}_{\mathrm{P}}$. The enamel was recovered using a rotary drill with a diamondtipped dental burr. Following Sponheimer and Lee-Thorp (2006) recommendations, the enamel was removed from as large an area of the tooth as possible to avoid biasing the isotopic results with respect to seasonality, thus producing an homogeneous signal from several months or years. The oxygen and carbon isotopic results are reported in the -notation against VPDB $\left({ }^{18} \mathrm{O}_{\mathrm{C} 3}\right.$ and $\left.{ }^{13} \mathrm{C}_{\mathrm{C} \bullet 3}\right)$ and VSMOW $\left({ }^{18} \mathrm{O}_{\mathrm{C} \bullet 3}\right.$ and $\left.\delta^{18} \mathrm{O}_{\mathrm{p} \bullet 4}\right) . \delta_{\text {sample }}=\left[\left(R_{\text {sample }}-R_{\text {standard }}\right) / R_{\text {standard }}\right] \times 1000$; with $R={ }^{18} \mathrm{O} /{ }^{16} \mathrm{O}$ and ${ }^{13} \mathrm{C} /{ }^{12} \mathrm{C}$.

$\delta^{18} \mathrm{O}_{\mathrm{C} \cdot 3}$ and $\delta^{13} \mathrm{C}_{\mathrm{C} \bullet 3}$ analyses were conducted at the University of Plymouth (United Kingdom) using an acid digestion technique with a continuous helium flow GVI IsoPrime with a multiflow preparation system. Approximately 6-7 $\mathrm{mg}$ of sample were weighed into individual, septum sealed, vials and placed on a hot plate maintained at $90{ }^{\circ} \mathrm{C}$. Each vial was automatically flushed with helium before excess $\mathrm{H}_{3} \mathrm{PO}_{4}$ was added. After approximately $24 \mathrm{~h}$ of equilibration time the $\mathrm{CO}_{2}$ was analyzed by continuous flow Mass Spectrometry. The in run NBS-19 standard gave a $\delta^{18} \mathrm{O}$ value of $-2.11 \pm 0.12 \%$ (VPDB) $(n=5)$ and a $\delta^{13} \mathrm{C}$ value of $1.83 \pm 0.13 \%$ (VPDB) $(n=5)$. External reproducibility of the carbonate in the bioapatite was checked by analysing NBS 120c Florida phosphate rock. The following values were obtained for this standard; ${ }^{18} \mathrm{O}=-2.24 \pm 0.52 \%$ (VPDB) $(n=3)$ and $\delta^{13} \mathrm{C}=-6.21 \pm 0.54 \%$ (VPDB) $(n=3)$. Tütken et al. (2006, 2007) reported values of $\delta^{18} \mathrm{O}=-2.32 \pm 0.14 \%$ (VPDB) and ${ }^{13} \mathrm{C}=-6.29 \pm$ $0.08 \%$ (VPDB) for this standard. The previous isotopic analyses provided by Cuevas-González (2006) on herbivore dental enamel from Somosaguas site were carried out at the Servicio General de Análisis de Isótopos Estables (Universidad de Salamanca, Spain). $\mathrm{CO}_{2}$ from all samples was obtained by acid hydrolysis using pure phosphoric acid $\left(\mathrm{H}_{3} \mathrm{PO}_{4}\right)$ with a reaction time of $24 \mathrm{~h}$ at $25{ }^{\circ} \mathrm{C}$. Isotopic ratios were determined in a SIRA II mass spectrometer. The international NBS-19 standard gave a $\delta^{18} \mathrm{O}$ value of $-2.23 \pm 0.05 \%$ (VPDB) $(n=4)$ and a $\delta^{13} \mathrm{C}$ value of $1.95 \pm 0.02 \%$ (VPDB) $(n=4)$.

Forty ${ }^{18} \mathrm{O}_{\mathrm{P}}$ analyses were conducted at Royal Holloway University of London (United Kingdom) using the direct laser fluorination (DLF) technique described by lindars et al. (2001) which requires $\sim 2 \mathrm{mg}$ of sample. The pre-treatment involves heating the samples up to $400{ }^{\circ} \mathrm{C}$ for 
$1 \mathrm{~h}$ and fusing under high vacuum in the sample chamber with the aim of removing the organic matter, $\mathrm{CO}_{3}^{2-}$ and $\mathrm{OH}^{-}$. The $\mathrm{CO}_{2}$ laser at $25 \mathrm{~W}$ produces a thermic reaction in presence of $\mathrm{BrF}_{5}$ that leads to the release of $100 \%$ oxygen from the phosphate. The resulting $\delta^{18} \mathrm{O}_{\mathrm{P}}$ values were analyzed by using a GV Optima dual inlet mass spectrometer. The standard used was NBS 120c Florida phosphate rock that showed a value of $21.13 \pm 0.51 \%$ (VSMOW) ( $n=12$ ). Vennemann and Hegner (1998), Lécuyer et al. (2003b) and Amiot et al (2007) reported $\delta^{18} \mathrm{O}_{\mathrm{P}} \bullet$ values for NBS $120 \mathrm{c}$ of $21.5 \pm 0.20 \%$, $21.65 \pm 0.15 \%$ and $21.7 \pm 0.20 \%$.

The remaining $11 \delta^{18} \mathrm{O}_{\mathrm{p}}$ analyses were performed at the Servicio General de Análisis de Isótopos Estables (Universidad de Salamanca, Spain). The samples were processed to obtain $\mathrm{Ag}_{3} \mathrm{PO}_{4}$ following the procedure proposed by Dettman et al. (2001) with slight modifications. Between 5 and $10 \mathrm{mg}$ of sample were dissolved in $2 \mathrm{ml} \mathrm{HF} 2 \mathrm{M}$. The solution was centrifuged and the solid $\mathrm{CaF}_{2}$ residue was rinsed twice with $8 \mathrm{ml}$ of distilled water. The wash water was then added to the solution containing the phosphate ions and the solid residue left behind. The final dissolution was neutralised by addition of $1.6 \mathrm{ml}$ of $6 \% \mathrm{NH}_{4} \mathrm{OH}$ solution. The rapid precipitation of $\mathrm{Ag}_{3} \mathrm{PO}_{4}$ was produced after adding $2 \mathrm{ml}$ of $\mathrm{AgNO}_{3} 2 \mathrm{M}$. The $\mathrm{Ag}_{3} \mathrm{PO}_{4}$ crystals were separated by centrifugation and rinsed twice with distilled water. The $\mathrm{Ag}_{3} \mathrm{PO}_{4}$ was finally oven-dried overnight at $\sim 60^{\circ} \mathrm{C}$. The $\mathrm{Ag}_{3} \mathrm{PO}_{4}$ was weighed in silver foil capsules along with nickelised carbon in an approximate weight ratio of $1: 1$, and analyzed for its oxygen isotopic composition by pyrolysis in a EuroVector EA3028-HT elemental analyser coupled on line to a GVI IsoPrime mass spectrometer. Three different silver phosphate standards were used to perform the off-line normalization of the results: TU-1 and TU-2 (Vennemann et al., 2002) whose measured $\delta^{18} \mathrm{O}$ values are $21.14 \pm 0.05 \%$ (VSMOW) $(n=4)$ and 5.52 $\pm 0.08 \%$ 。(VSMOW) $(n=4)$, respectively, and SfT- 1 prepared at the Servicio General de Análisis de Isótopos Estables (Universidad de Salamanca, Spain) and with a $\delta^{18} \mathrm{O}$ value of $11.62 \%$ (VSMOW). The different standards used cover the range of isotopic variation of the samples.

\section{Results}

\subsection{Scanning Electron Microscope}

Fig. 4 shows that the $\mathrm{F} / \mathrm{P}$ and $\mathrm{Ca} / \mathrm{P}$ ratios of the mammal enamel from Somosaguas are closer to the composition of carbonate hydroxyapatite, which is considered to represent the original miner- alogy when dealing with osseous samples, in contrast with that of fluorapatite, regarded as the altered mineralogy (Hubert et al., 1996; Kolodny et al., 1996; Grimes et al., 2003; Nemliher et al., 2004). Based upon this evidence it can be argued that the Somosaguas samples retain a reliable geochemical signal, affected at most only by a low degree of diagenetic alteration.

On the other hand, Zazzo et al. (2004) stated that microbially induced alterations may produce important changes in the $\delta^{18} \mathrm{O}_{\mathrm{P}}$ value. SEM images obtained from the herbivore tooth enamel from Somosaguas site (Fig. 5) did not show evidence of microorganisms affecting this tissue during the fossilization process and therefore it can be assumed that pristine $\delta^{18} \mathrm{O}_{\mathrm{p}}$ values have been maintained.

\subsection{Rare Earth Elements (REE)}

Table 1 shows the raw REE values obtained from the different taxa analyzed at the Somosaguas site. It can be observed that the total REE concentrations obtained from mammal enamel vary from 17.11 to $98.65 \mathrm{ppm}$. Other authors have also investigated REE concentrations in terrestrial fossil vertebrate bioapatite (Elorza et al., 1999; Metzger et al., 2004; Martin et al., 2005; Trueman et al., 2006). However, the vast majority of studies deal preferentially with fossil bone that traditionally has been considered more prone to suffer diagenetic effects. Furthermore, REEs detected in fossil bones and teeth are believed to be a reflection of the pore water composition during burial (Trueman, 1999) and have previously been used to determine the degree of alteration. Previous fossil bone studies have shown total REE concentrations higher than 200 ppm (Lécuyer et al., 2003b). Furthermore, the enamel of a horse analyzed by Martin et al. (2005) at Pleistocene Fossil Lake Area (Oregon, USA) provided REE values of $>1000 \mathrm{ppm}$. The low REE concentrations observed in mammal enamel from Somosaguas may be indicative of at most only early stage diagenesis with a low concentration of these elements being present in the pore water during fossilization.

Fig. 6 shows the REEs patterns provided by the mammal enamel. According to Reynard et al. (1999) and Lécuyer et al. (2003b) a flat REE profile indicates the absence of late stage diagenesis and recrystallization. In contrast, the "bell shaped" REE patterns (enrichment of MREE) is the result of extensive recrystallization of the apatite in the presence of REE-bearing fluids. The majority of the

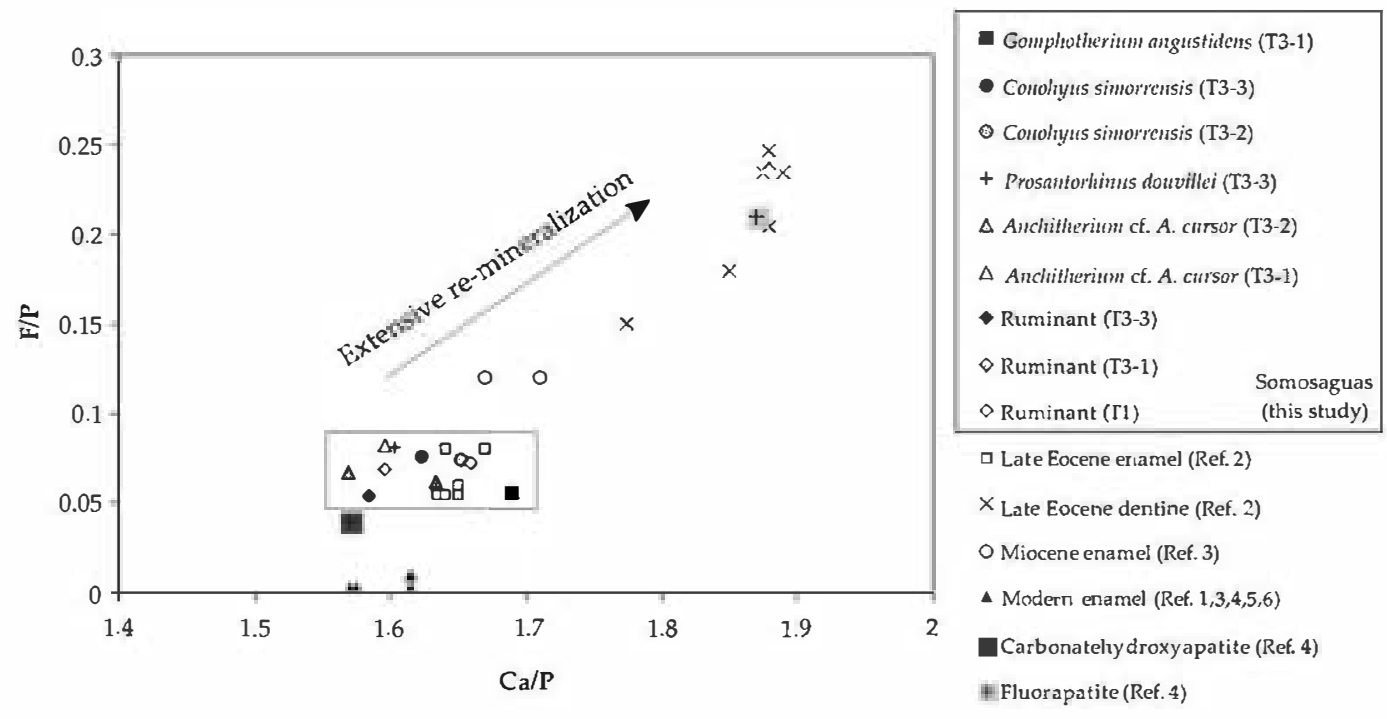

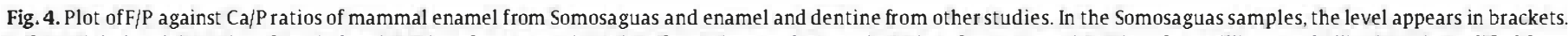

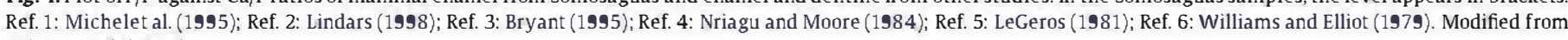
Grimes et al. (2003). 
a)

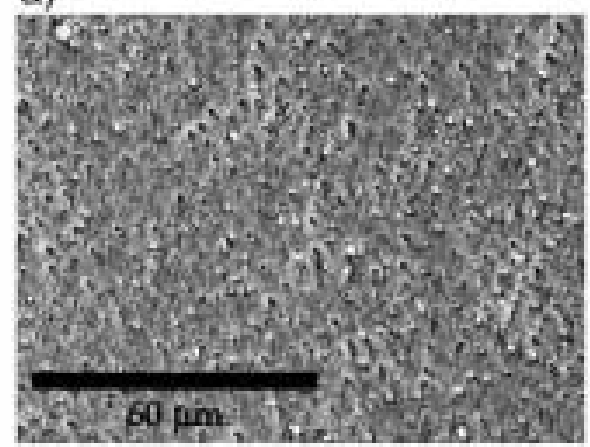

c)

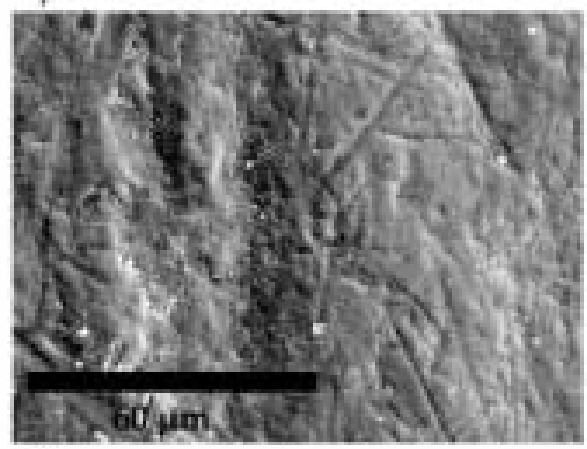

e)

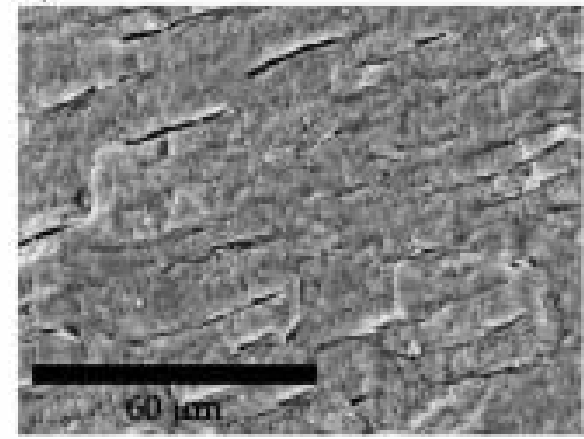

b)

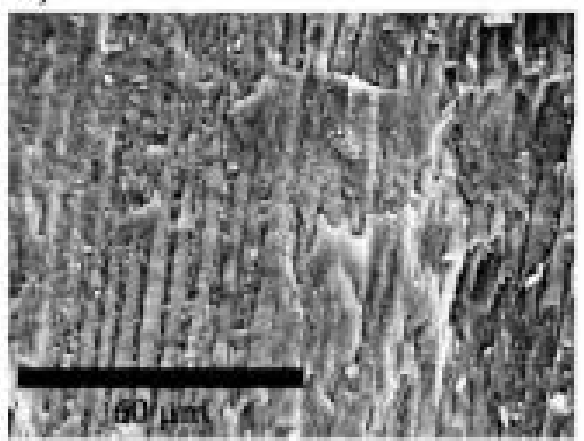

d)

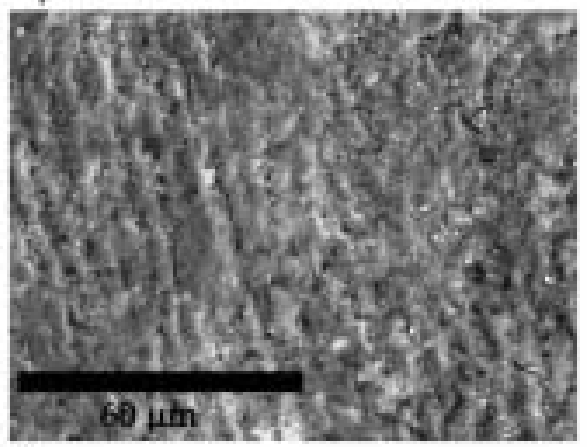

f)

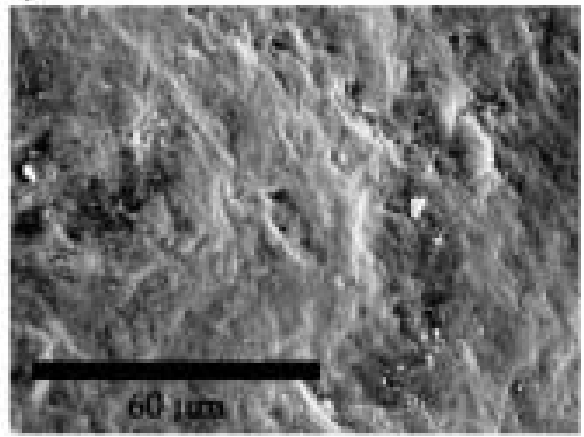

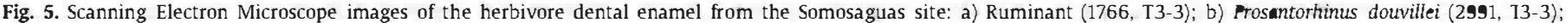
c) Anchitherium cf. A. cursor (1611, T3-2); d) Anchitherium cf. A. cursor (2848, T3-2); e) Anchitherium cf. A. cursor (3120, T3-1); f) Ruminant (2453, T3-1).

samples from Somosaguas have a flat REE pattern (Fig. 6), which in a similar manner to the REE concentrations is indicative of at most a low degree of diagenetic alteration of the mammal enamel from this site.

Finally, in light of SEM and REE analyses, no extensive inorganic alteration seems to have affected the herbivore tooth enamel from the Somosaguas site. According to Zazzo et al. (2004), this is important as it suggests that the $\varepsilon^{18} \mathrm{O}_{\mathrm{c} \bullet 3}$ signal has not been modified.

\subsection{Stable isotopes}

\subsection{1. $8^{18} 0$}

Fig. 7 shows the $\delta^{18} \mathrm{O}_{\mathrm{c} \bullet 3}$ and $\delta^{18} \mathrm{O}_{\mathrm{p} \bullet 4}$ values provided by herbivore mammal enamel from Somosaguas. It should be noted that the difference between both fractions (carbonate and phosphate) is close to the ideal isotopic equilibrium fractionation shown by other authors ( 8.6 to $9.1 \%$; Bryant et al., 1996; Iacumin et al., 1996; Fricke et al., 1998). Once more, this relationship indicates a low degree of diagenetic alteration in the enamel samples from Somosaguas and agrees well with a previous study carried out at the Somosaguas site (Hernández Fernández et al., 2006).

Fig. 8a and Table 2 show the evolution of ${ }^{18} \mathrm{O}_{\mathrm{C} \bullet 3}$ values from $\mathrm{T} 1$ to T3-3. A trend towards lower isotopic values can be observed as far as
Gomphotherium angustidens and Anchitherium cf. A. cursor are concerned. Conohyus simorrensis shows this same pattern if $\mathrm{T} 1$ is not considered. Ruminants do not show a clear pattern across the stratigraphic succession. Statistically significant differences have been obtained among the different stratigraphic levels, when lumping all species, as reported through an ANOVA test $(F=4.559$ and $p=0.005$ ).

As mentioned before, $\delta^{18} \mathrm{O}$ values are indicative of the isotopic composition of meteoric water which is related to mean annual temperature (MAT). The drop across the successive stratigraphic levels in tooth enamel ${ }^{18} \mathrm{O}_{\mathrm{C} \bullet 3}$ values for Gomphotherium angustidens, Anchitherium cf. A. cursor and Conohyus simorrensis may therefore be indicative of a decrease in the $\delta^{18} \mathrm{O}$ of the meteoric water and in turn to a drop in the temperature.

Interspecific differences in $\delta^{18} \mathrm{O}_{\mathrm{C} \bullet}$ values can also be interpreted from a palaeoecological point of view (Bocherens et al., 1996; Kohn, 1996; Sponheimer and Lee-Thorp, 1999). In Fig. 8a, it can be observed that, except for the level T1, Gomphotherium angustidens has a lower $\delta^{18} \mathrm{O}_{\mathrm{c} \bullet}$ value compared to that provided by Anchitherium cf. A cursor. Although both taxa are considered to be browsers, it has been suggested that Anchitherium cf.A. cursor could have had a better adaptation to open habitats (Sánchez et al., 1998; Salesa and Sánchez, 2000; Hemández Femández et 
Table 1

Raw Rare Earth Element (REE) values for the herbivore tooth enamel analyzed in Somosaguas

\begin{tabular}{|c|c|c|c|c|c|c|c|c|c|c|c|c|c|c|c|c|}
\hline level & Taxa & $n$ & La & Ce & $\mathrm{Pr}$ & Nd & Sm & Eu & Gd & $\mathrm{Tb}$ & Dy & Ho & Er & $\mathrm{Yb}$ & Lu & ¿REE \\
\hline & & & $(\mathrm{ppm})$ & (ppm) & $(\mathrm{ppm})$ & $(\mathrm{ppm})$ & $(\mathrm{ppm})$ & $(\mathrm{ppm})$ & $(\mathrm{ppm})$ & $(\mathrm{ppm})$ & $(\mathrm{ppm})$ & $(\mathrm{ppm})$ & $(\mathrm{ppm})$ & $(\mathrm{ppm})$ & $(\mathrm{ppm})$ & (ppm) \\
\hline \multirow[t]{5}{*}{ T33 } & Gomphotherium angustidens & 8 & 20.86 & 17.76 & 6.52 & 26.43 & 6.26 & 1.04 & 5.59 & 0.95 & 4.53 & 0.88 & 2.07 & 1.33 & 0.26 & 94.49 \\
\hline & Anchitherium of. A. cursor & 8 & 12.90 & 6.42 & 2.48 & 9.38 & 2.04 & 0.43 & 2.16 & 0.42 & 2.04 & 0.54 & 1.23 & 0.85 & 0.20 & 41.09 \\
\hline & Ruminant & 2 & 12.70 & 14.40 & 11.36 & 13.32 & 10.80 & 2.31 & 11.04 & 1.80 & 10.08 & 1.88 & 5.03 & 3.35 & 0.57 & 98.65 \\
\hline & Conohyus simorrensis & 5 & 6.71 & 10.61 & 2.08 & 14.49 & 3.52 & 0.69 & 3.45 & 0.64 & 3.22 & 0.74 & 1.78 & 1.30 & 0.26 & 49.49 \\
\hline & Prosantorhinus douvillei & $t$ & 17.34 & 6.51 & 5.63 & 17.84 & 4.04 & 0.56 & 4.52 & 0.62 & 3.32 & 0.53 & 1.85 & 0.73 & 0.99 & 64.48 \\
\hline \multirow[t]{5}{*}{ T3-2 } & Gomphotherium angustidens & 8 & 14.67 & 10.03 & 2.78 & 10.43 & 2.27 & 0.46 & 2.49 & 0.47 & 2.32 & 0.58 & 1.34 & 1.00 & 0.23 & 49.07 \\
\hline & Anchitherium cf. A. cursor & 6 & 12.00 & 12.98 & 2.86 & 11.09 & 2.54 & 0.49 & 2.71 & 0.49 & 2.41 & 0.56 & 1.23 & 0.87 & 0.20 & 50.42 \\
\hline & Ruminant & 1 & 9.44 & 14.96 & 3.16 & 12.40 & 3.22 & 0.46 & 3.19 & 0.60 & 2.68 & 0.57 & 1.26 & 0.84 & 0.18 & 52.96 \\
\hline & Conohyus simorrensis & 2 & 5.12 & 5.37 & 0.96 & 26.34 & 5.78 & 1.19 & 6.52 & 1.12 & 6.07 & 1.28 & 3.39 & 2.61 & 0.48 & 66.22 \\
\hline & Prosantorhinus douvillei & t. & 16.64 & 7.11 & 4.56 & 18.48 & 4.17 & 0.76 & 3.81 & 0.72 & 3.44 & 0.71 & 1.62 & 0.97 & 0.20 & 63.18 \\
\hline \multirow[t]{4}{*}{ T3-1 } & Gomphotherium angustidens & 8 & 12.51 & 15.00 & 3.01 & 11.74 & 2.77 & 0.51 & 2.94 & 0.55 & 2.69 & 0.62 & 1.47 & 1.04 & 0.22 & 55.06 \\
\hline & Anchitherium of. A. cussor & 3 & 6.13 & 1.91 & 1.03 & 3.41 & 0.88 & 0.22 & 0.81 & 0.21 & 0.88 & 0.31 & 0.66 & 0.53 & 0.15 & 17.11 \\
\hline & Ruminant & 4 & 7.42 & 3.10 & 3.04 & 10.91 & 2.11 & 0.49 & 2.54 & 0.45 & 2.20 & 0.57 & 1.45 & 1.14 & 0.25 & 35.66 \\
\hline & Conohyus simorrensis & 1 & 7.75 & 10.00 & 1.78 & 6.41 & 1.45 & 0.35 & 1.57 & 0.32 & 1.41 & 0.39 & 0.86 & 0.59 & 0.16 & 33.04 \\
\hline \multirow[t]{3}{*}{$\mathrm{T} 1$} & Anchitherium of. A. cursor & $\mathrm{t}$ & 23.40 & 7.02 & 7.36 & 8.16 & 3.48 & 5.46 & 3.54 & 5.23 & 3.72 & 6.39 & 2.63 & 3.34 & 8.64 & 88.37 \\
\hline & Ruminant & $\mathrm{t}-$ & 21.48 & 6.48 & 3.67 & 17.36 & 5.93 & 1.98 & 7.83 & 2.16 & 11.36 & 2.13 & 5.52 & 3.90 & 0.68 & 90.48 \\
\hline & Conohyus simorrensis & 2 & 25.40 & 7.92 & 8.08 & 18.46 & 8.04 & 1.20 & 5.90 & 1.64 & 8.61 & 1.68 & 2.42 & 2.82 & 0.49 & 92.66 \\
\hline
\end{tabular}

$n$ is the number of analyzed samples.

al, 2003) and as a result this species may have fed on some forbs that are more prone to suffer from evaporation compared to tree or shrub leaves. This could explain the higher enamel $\delta^{18} \mathrm{O}_{\mathrm{Co}}$ values of the Somosaguas horse. The suid Conohyus simorrensis provides the lowest $\delta^{18} \mathrm{O}_{\mathrm{c} \bullet 3}$ value (apart from levels T3-1 and 13-3). Bocherens et al. (1996), Sponheimer and Lee-Thorp (2001) and Lee-Thorp and Sponheimer (2003) also found low isotopic values for the suids when studying different extant and extinct taxa from Africa. These authors stated that this may be due to the strong dependency suids show for the underground rhizomes which have low isotopic plant-water values. In the case of the ruminants, several species were grouped so the interpretation of results is more complicated. ANOVA test only shows significant differences among taxa in the case of level T3-3 (T1: $F=1.840$ and $p=0.280 ; \mathrm{T} 3-1: F=1.768$ and $p=0.194$; T3-2: $F=1.085$ and $p=0.397 ; 13-3: F=0.729$ and $p=0.004$ ).

$\delta^{18} \mathrm{O}_{\mathrm{P}}$ values across T3-1, T3-2 and T3-3 are shown in Fig. 8b and Table 2 (analyses of ${ }^{18} \mathrm{O}_{\mathrm{P}}$ in the level T1 could not be done due to the shortage of material). A decrease in the isotopic values of Gomphotherium angustidens, Anchitherium cf. A. cursor, Conohyus simorrensis and ruminants can be observed, similar to the trend in the $\delta^{18} \mathrm{O}_{\mathrm{C} \bullet 3}$ values. ANOVA tests show statistically significant differences
T3-3

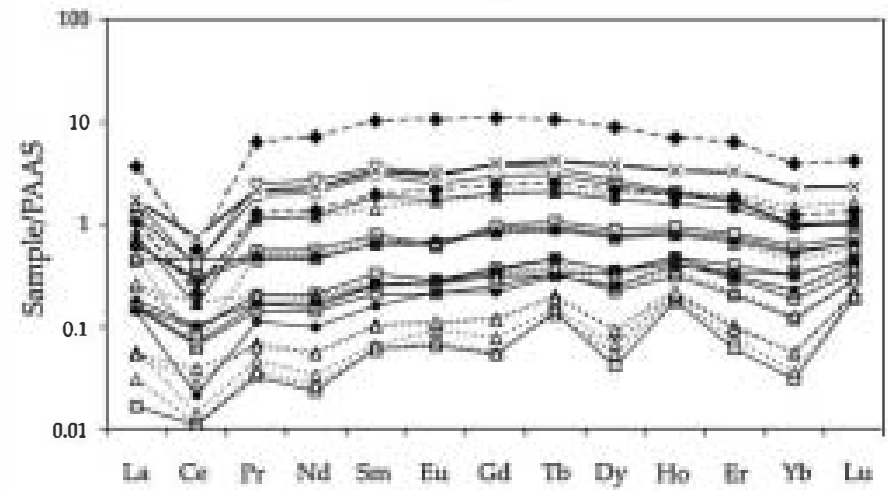

T3-1

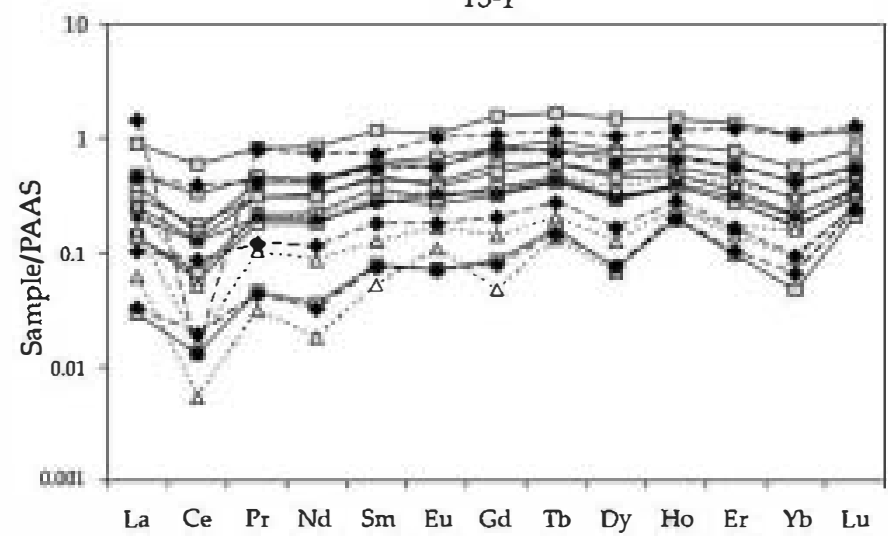

T3-2

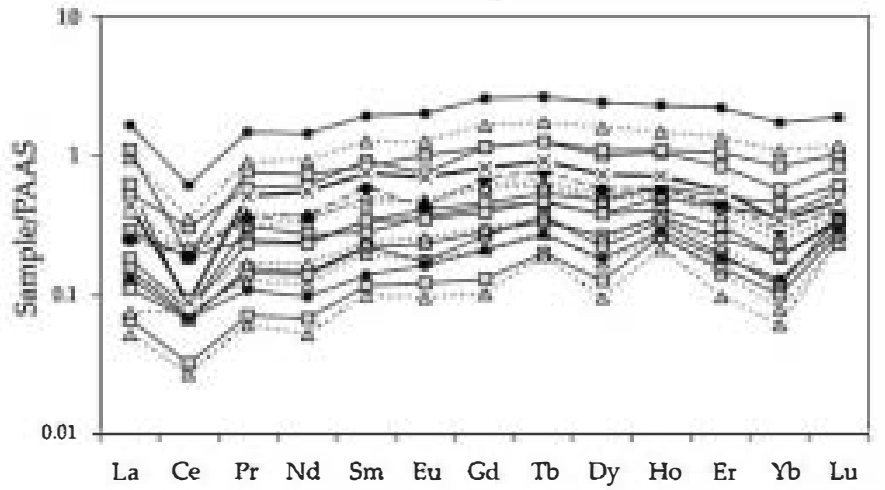

T1

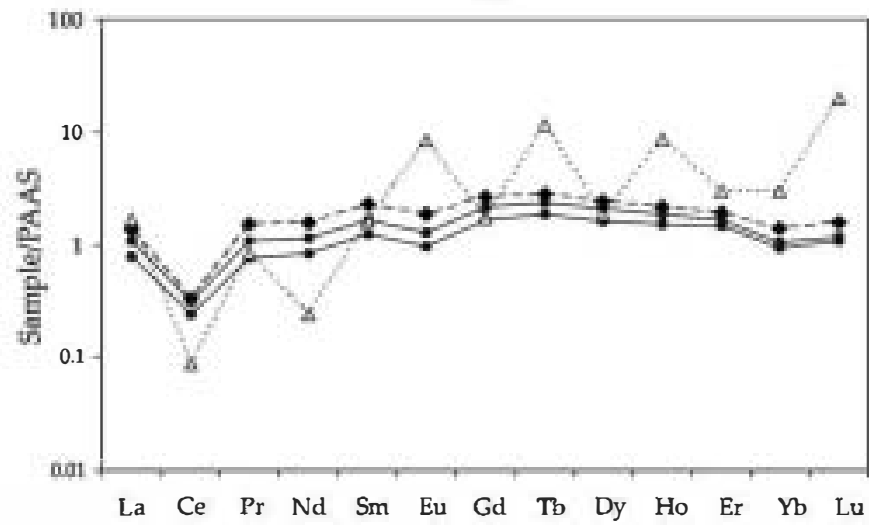

Fig. 6. Rare Earth Elements (REEs) patterns of the mammal enamel from Somosaguas in levels T3-3, T3-2, T3-1 and T1. Grey square: Gomphotherium angustidens, white triangle: Anchitherium cf. A. cursor, black diamond: ruminant, grey circle: Conolyus simorrensis, cross: Prosantorhinus douvillei. PAAS values (Post-Archean Australian Shale of Taylor and McLennan, 1985) were used to normalize the raw REE data. 

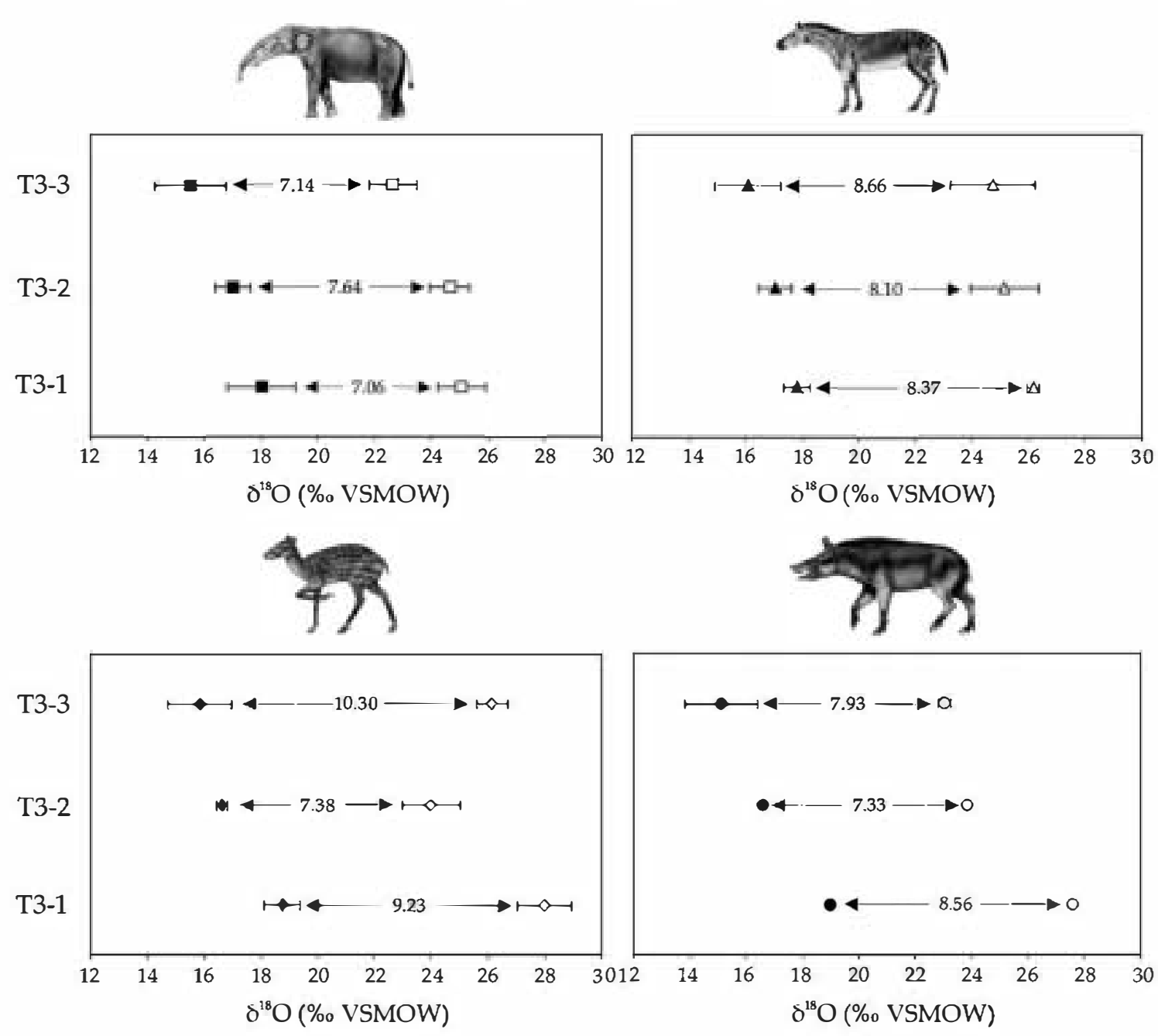

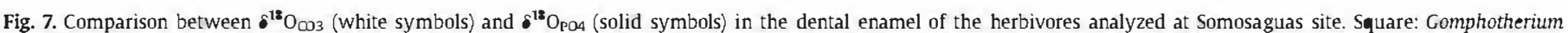
angustidens, triangle: Anchitherium cf. A. cursor, diamond: ruminants, circle: Conohyus simorrensis. Mammal reconstructions by Sergio Pérez, not to scale.

between levels in the case of Comphotherium angustidens ( $F=14.194$ and $p<0.001)$, Anchitherium of. A. cursor $(F=3.712$ and $p=0.062)$ and ruminants $(F=12.728$ and $p=0.011)$, and between the different levels when including all species $(F=28.132$ and $p<0.001)$.

The Eqs. (1)-(5) used in this study to calculate $\delta^{18} \mathrm{O}_{\mathrm{H} 2}$ values are those proposed by Tütken et al. (2006):

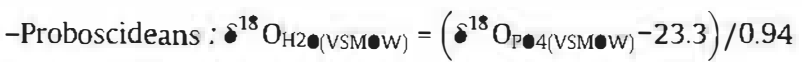

(Ayliffe et al., 1992)

-Equids : $\delta^{18} \mathrm{O}_{\text {heopsan }}=\left(\delta^{18} \mathrm{O}_{\text {pourssuow }}-22.6\right) / 0.77$

(Huertas et al., 1995)

-Ruminants: $\delta^{18} \mathrm{O}_{\mathrm{H} 2 \bullet(\mathrm{VSM} \bullet \mathrm{W})}=\left(\delta^{18} \mathrm{O}_{\mathrm{P}} \bullet 4(\mathrm{VSM} \bullet \mathrm{W})-25.53\right) / 1.13$

(D'Angela and Longinelli, 1990)

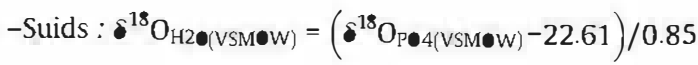

(Longinelli, 1984)

-Rhinocerotids : $\left.{ }^{18} \mathrm{O}_{\mathrm{H} 2 \bullet(\mathrm{VSM} \bullet \mathrm{W})}=\left(\delta^{18} \mathrm{O}_{\mathrm{P}} \bullet_{(\mathrm{VSM}} \mathrm{VW}\right)-25.09\right) / 1.31$

(Tütken et al., 2006)
Fig. 9 shows a statistically significant drop across levels (ANOVA: $F=26.706$ and $p<0.001)$ in $\delta^{18} \mathrm{O}_{\mathrm{H} 2}$ values from a mean value of $-5.8 \pm 0.5 \%$ (VSMOW) in T3-1 to a mean value of $-8.0 \pm 0.2 \%$ (VSMOW) in T3-3. This consistent decrease in $\delta^{18} \mathrm{O}_{\mathrm{H} 2}$ values across the succession suggests a drop in the temperature from the deposition of level T3-1 to the deposition of level T3-3, which can be observed when quantifying mean annual temperature (MAT) by using Yurtsever and Gat (1981)'s equation:

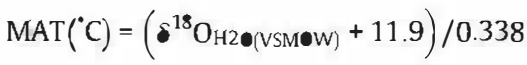

Subsequently, a statistically significant decrease in MAT across levels (ANOVA: $F=26.706$ and $p<0.001$ ) values can be observed in Fig. 9 from an average MAT value of $17.8 \pm 1.1^{\circ} \mathrm{C}$ in T3-1 to an average MAT value of $11.6 \pm 0.7{ }^{\circ} \mathrm{C}$ in T3-3.

As said before, $\delta^{18} \mathrm{O}_{\mathrm{p}}$ analyses could not be performed on the enamel from $\mathrm{T} 1$ due to the shortage of material. However, in a previous study carried out by Hernández Fernández et aL. (2006), MAT values were calculated by using $\delta^{18} \mathrm{O}_{\mathrm{C} \bullet 3}$ values and estimating $\delta^{18} \mathrm{O}_{\mathrm{P} \bullet 4}$ from Iacumin et al. (1996)'s equation. In this study a MAT value of $\sim 26.6 \pm 4.9{ }^{\circ} \mathrm{C}$ was obtained for $\mathrm{T} 1$ level. This result agrees with the whole recorded trend of temperature drop as explained above.

When applying Eqs. (1)-(5) the user should be aware of certain limitations. Firstly, all of the equations were derived using very specific taxa. Therefore, their application to larger groups requires the assumption that they have similar overall metabolisms. Secondly, 

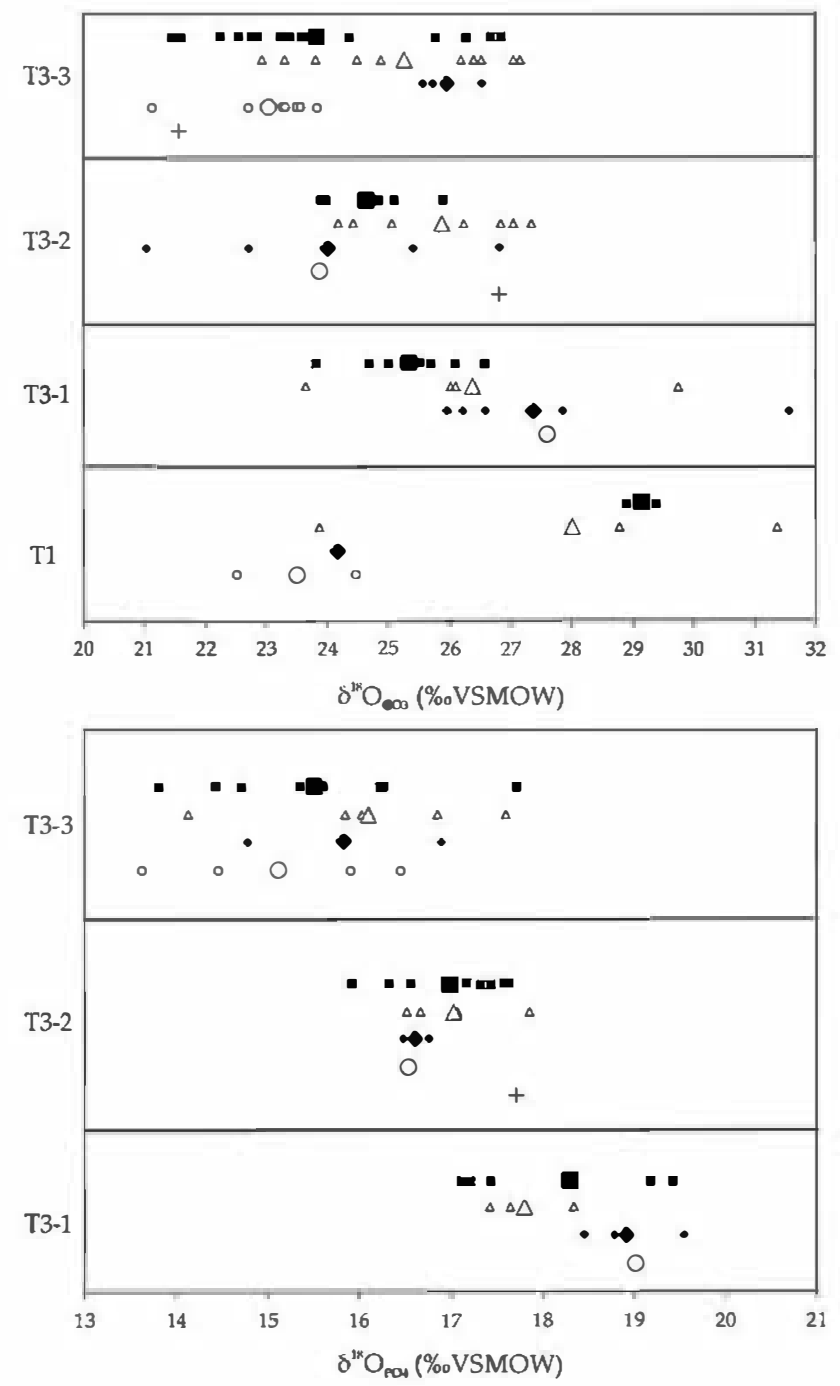

Fig. 8. Evolution of a) $\delta^{18} \mathrm{O}_{\mathrm{cos}}$ and b) $\delta^{18} \mathrm{O}_{\mathrm{PO}}$ values (\%vSMOW) from levels $\mathrm{T} 1$ to $\mathrm{T} 3-3$ and T3-1 to T3-3, respectively. Black square: Gomphotherium angusidens, white triangle: Anchitherium of. A. cursor, blackdiamond: ruminant, white circle: Conohyus simorrensis, cross: Prosantorhinus douvillei. larger symbols represent the mean isotopic value.

some of the equations were derived using modern taxa whose physiology is well known. By applying them to extinct taxa, vital effects are obviated. The application of Eq. (6) also has some drawbacks. The main drawback is related to the fact that it was not originally designed to be applied to ${ }^{18} \mathrm{O}_{\mathrm{H} 2}$ local water values obtained from tooth enamel $\delta^{18} \mathrm{O}_{\mathrm{p}}$ values, but rather to $\delta^{18} \mathrm{O}_{\mathrm{H} 2 \mathrm{O}}$ precipitation values. However, due to the fact that other authors have demonstrated that the application of this equation gives a good approximation for temperature values when considering $\delta^{18} \mathrm{O}_{\mathrm{H} 2 \mathrm{O}}$ local water values (Straight et al., 2004; Tüitken et al., 2006), we agree to use it in this study.

\subsection{2. $\delta^{13} \mathrm{C}$}

Fig. 10 and Table 2 show the tooth enamel $\delta^{13} \mathrm{C}_{\mathrm{C}}$ values from the taxa analyzed at Somosaguas. Isotopic values are close to those provided by $\mathrm{C}_{3}$ plant-feeders. However, it can be observed that ${ }^{13} \mathrm{C}_{\mathrm{C}}$ values from the herbivores of Somosaguas are close to the upper limit of typical ${ }^{13} C_{C}$ values of $C_{3}$ plant eaters $(\sim-8 \%$ ). This fact may be indicative of the existence of a small proportion of $C_{4}$ plants in the diet or of the presence of xeric vegetation widely affected by evaporation processes. Both interpretations are compa- tible with the proposed savannah for Somosaguas during the Middle Miocene (López-Martínez et al., 2000; Hernández Fernández et al., 2003, 2006).

Statistically significant differences are obtained by an ANOVA test when comparing the four stratigraphic levels from Somosaguas site $(F=4.884$ and $p=0.004)$. There exists a small decrease in ${ }^{13} C_{\mathrm{C} \bullet}$ values from $\mathrm{T} 1$ to $\mathrm{T} 3-1$, probably indicative of a change towards more humid conditions, although the difference in the $\delta^{13} \mathrm{C}_{\mathrm{C} \cdot 3}$ values between the two levels is not statistically significant (Post-hoc Tukey's test: $p=0.985$ ). Subsequently, from T3-1 to $\mathrm{T} 3-3,{ }^{13} \mathrm{C}$ values from Gomphotherium angustidens and Anchitherium cf. A. cursor show a general increase that may be related to a shift towards drier conditions (Fricke and O'Neil, 1996). A statistically significant difference is observed in $\delta^{13} \mathrm{C}_{\mathrm{C} 3}$ values between T3-1 and T3-3 (Post-hoc Tukey's test: $p=0.009$ ).

When considering the total mean $\delta^{13} \mathrm{C}_{\mathrm{CO} 3}$ value of each species, it can be observed that Prosantorhinus douvillei shows the lowest value $(-11.5 \pm 2.5 \%$ o), followed by Conohyus simorrensis $(-10.2 \pm 1.6 \%)$, Gomphotherium angustidens $(-10.0 \pm 1.1 \%$ ). Anchitherium cf. A. cursor $(-9.8 \pm 1.1 \%$ o $)$ and the ruminants $(-9.5 \pm 1.2 \%$ ). In spite of the small differences (ANOVA: $F=1.542$ and $p=0.198$ ), lower $\delta^{13} C_{\text {Co3 }}$ values would be indicative of a more browsing behaviour, whereas higher ${ }^{13} \mathrm{C}_{\mathrm{CO}}$ values observed in Anchitherium of. $A$. cursor and the ruminants would suggest a diet selection towards plant species with a higher evaporation rate. The higher isotopic values obtained in the ruminants may also be indicative of differences in their digestive tracts. Ruminants produce high quantities of methane during their digestion as a consequence of the foregut microbial fermentation (Passey et al., 2005). This fact may give rise to enriched $\delta^{13} \mathrm{C}_{\mathrm{C}}$ values compared to other mammals with hindgut digestion. In Fig. 10, it can be observed that in levels $\mathrm{T} 1$ and T3-1, ruminants show the highest ${ }^{13} \mathrm{C}_{\mathrm{C}}$ values, however, this cannot be seen in levels T3-2 and T3-3. Statistically significant differences have only been obtained in level T3-1 when applying t-Student test to every level comparing ruminants vs. non-ruminants taxa (T1: $t=-1.437$, $p=0.201$; T3-1: $t=-2.976, p=0.008 ;$ T3-3: $t=0.135, p=0.894 ;$ T3-3: $t=-0.138, p=0.891$ ). It is interesting to point out that T3-1, which as previously stated is the most humid level and therefore the vegetation would probably be more diverse, is also the one where the two functional groups of large herbivores seem to show a larger capability to discriminate among different dietary resources. Nevertheless, an unequivocal conclusion concerning this issue cannot be attained unless a further number of analyses are carried out.

\subsection{Ba/Ca ratio}

When considering all the levels independently, no statistically significant differences are found among different taxa by means of ANOVA test ( T3-1: $F=1.724, p=0.215$; T3-2: $F=3.132, p=0.062$; T3-3: $F=0.952, p=0.453)$. Nevertheless, within the Somosaguas samples, it can be seen that the ruminants show the highest $\mathrm{Ba} / \mathrm{Ca}$ ratio $(0.8 \pm 0.4)$ of the assemblage. Anchitherium cf. A. cursor has a higher value $(0.6 \pm$ $0.3)$ than Gomphotherium angustidens $(0.4 \pm 0.1)$, while Prosantorhinus douvillei has a value similar to that showed by Gomphotherium angustidens $(0.4 \pm 0.1)$. Finally, Conohyus simorrensis has the lowest value $(0.3 \pm 0.1)$ of the assemblage (Table 3, Fig. 11). Ruminants have the highest Ba/Ca ratio, not only when considering all stratigraphic levels but also in each level separately. This same feature was obseived by Balter et al. (2002).

Mammals discriminate the barium with respect to the calcium in the digestive tract and the kidneys in a process called biopurification of the calcium (Legget, 1992; Sips et al., 1997). The enrichment of barium in ruminants may be related to a longer time of retention of the ingested food and to a major efficiency of the cellulose degradation (Balter et al., 2002). These authors stated that the enrichment in barium in ruminants, when compared to horses and 
Table 2

$\delta^{13} \mathrm{C}_{\mathrm{CO} 3}\left(\%\right.$ VPDB), $\boldsymbol{\delta}^{12} \mathrm{O}_{\mathrm{CO} 3}\left(\%\right.$ VPDB, \%.VSMOW) and $\boldsymbol{\delta}^{12} \mathrm{O}_{\mathrm{PO} 4}(\%$ vSMOW) values from the herbivore tooth enamel analyzed in Somosaguas

\begin{tabular}{|c|c|c|c|c|c|c|}
\hline \multirow[t]{2}{*}{ Sample } & \multirow[t]{2}{*}{ Taxa } & \multirow[t]{2}{*}{ Ievel } & \multirow{2}{*}{$\frac{\delta^{13} \mathrm{C}_{\mathrm{CO} 3}}{\mathrm{VPDB})}$} & \multicolumn{2}{|l|}{$\delta^{18} \mathrm{O}_{\mathrm{CO} 3}$} & \multirow{2}{*}{$\begin{array}{l}\frac{\delta^{18} \mathrm{O}_{\mathrm{PO} 4}}{(\%} \\
\text { VSMOW) }\end{array}$} \\
\hline & & & & $\begin{array}{l}\% \\
\text { YPDB }\end{array}$ & $\begin{array}{l}\text { (\%o } \\
\text { VSMOWV }\end{array}$ & \\
\hline$\overline{3015}$ & Gomphotherium angustidens & $13-3$ & -9.82 & -9.17 & 21.46 & 14.43 \\
\hline 2431 & Gomphotherium angustidens & $13-3$ & -8.80 & -8.10 & 22.55 & 14.71 \\
\hline 2377 & Gomphotherium angustidens & $13-3$ & -10.27 & -7.29 & 23.39 & 17.72 \\
\hline 2214 & Gomphotherium angustidens & $13-3$ & -9.53 & -7.43 & 23.25 & 16.28 \\
\hline 2129 & Gomphotherium angustidens & $13-3$ & -10.28 & -7.10 & 23.59 & \\
\hline 1763 & Gomphotherium angustidens & $13-3$ & -10.68 & -9.03 & 21.60 & 15.61 \\
\hline 1562 & Gomphotherium angustidens & $13-3$ & -9.41 & -6.97 & 23.73 & 16.23 \\
\hline 914 & Gomphotherium angustidens & $13-3$ & -10.51 & -7.81 & 22.86 & 15.37 \\
\hline 598 & Gomphotherium angustidens & $13-3$ & -10.57 & -7.89 & 22.77 & 15.47 \\
\hline 170 & Gomphotherium angustidens & $13-3$ & -10.26 & -8.39 & 22.26 & 13.81 \\
\hline $\begin{array}{l}\text { SOMN-03- } \\
1831^{*}\end{array}$ & Gomphotherium angustidens & 13-3 & -9.93 & -4.09 & 26.69 & \\
\hline $\begin{array}{l}\text { SOMN-03- } \\
1551^{*}\end{array}$ & Gomphotherium angustidens & $13-3$ & -9.22 & -6.35 & 24.36 & \\
\hline $\begin{array}{l}\text { SOMN-02- } \\
\text { B11* }\end{array}$ & Gomphotherium angustidens & 13-3 & -10.47 & -3.93 & 26.86 & \\
\hline $\begin{array}{l}\text { SOMN-03- } \\
\text { A10* }\end{array}$ & Gomphotherium angustidens & $13-3$ & -9.23 & -4.48 & 26.29 & \\
\hline $\begin{array}{l}\text { SOMN-02- } \\
\text { 1085* }\end{array}$ & Gomphotherium angustidens & $13-3$ & -10.01 & -4.99 & 25.77 & \\
\hline 2890 & Anchitherium cf. A. cursor & $13-3$ & -10.16 & -4.37 & 26.40 & 17.61 \\
\hline 2821 & Anchitherium cf. A. cursor & 13-3 & -9.06 & -4.25 & 26.53 & 16.04 \\
\hline 2474 & Anchitherium cf. A. cursor & $13-3$ & -10.42 & -5.84 & 24.89 & 16.87 \\
\hline 2348 & Anchitherium cf. A. cursor & 13-3 & -9.89 & -7.73 & 22.94 & 14.14 \\
\hline 2323 & Anchitherium cf. A. cursor & 13-3 & -9.35 & -7.38 & 23.30 & 15.85 \\
\hline 2015 & Anchitherium cf. A. cursor & $13-3$ & -8.89 & -6.87 & 23.83 & \\
\hline 701 & Anchitherium cf. A. cursor & $13-3$ & -10.62 & -6.23 & 24.49 & 16.11 \\
\hline 154 & Anchitherium cf. A. cursor & T3-3 & -8.42 & -4.57 & 26.19 & \\
\hline $\begin{array}{l}\text { SOMN-03- } \\
1526^{*}\end{array}$ & Anchitherium cf. A. cursor & T3-3 & -8.44 & -3.62 & 27.18 & \\
\hline $\begin{array}{l}\text { SOMN-03- } \\
1676^{*}\end{array}$ & Anchitherium cf. A. cursor & T3-3 & -9.60 & -3.72 & 27.07 & \\
\hline 1766 & Ruminant & 13-3 & -10.04 & -5.16 & 25.59 & \\
\hline 1077 & Ruminant & $13-3$ & -7.82 & -4.25 & 26.53 & 16.91 \\
\hline 623 & Ruminant & 13-3 & -11.70 & -5.00 & 25.76 & 14.78 \\
\hline 2951 & Conohyus simorrensis & $13-3$ & -9.06 & -7.95 & 22.71 & \\
\hline 2579 & Conohyus simorrensis & $13-3$ & -10.89 & -6.87 & 23.83 & 15.92 \\
\hline 2357 & Conohyus simorrensis & $13-3$ & -9.97 & -7.42 & 23.26 & 14.46 \\
\hline 692 & Conohyus simorrensis & $13-3$ & -11.99 & -7.18 & 23.50 & 13.63 \\
\hline 635 & Conohyus simorrensis & $13-3$ & -8.90 & -7.13 & 23.56 & 16.46 \\
\hline 146 & Conohyus simorrensis & $13-3$ & -11.83 & -7.36 & 23.32 & \\
\hline $\begin{array}{l}\text { SOMN-02- } \\
1062^{*}\end{array}$ & Conohyus simorrensis & $13-3$ & -11.66 & -9.48 & 21.14 & \\
\hline 2991 & Prosantorhinus douvillei & 13-3 & -9.75 & -9.07 & 21.56 & \\
\hline 3090 & Gomphotherium angustidens & $13-2$ & -10.39 & -6.00 & 24.72 & 17.33 \\
\hline 2912 & Gomphotherium angustidens & 13-2 & $-\mathbf{9} .17$ & -6.10 & 24.62 & 16.33 \\
\hline 2895 & Gomphotherium angustidens & 13-2 & -6.21 & -6.71 & 23.99 & 15.92 \\
\hline 2867 & Gomphotherium angustidens & $13-2$ & -10.65 & -6.80 & 23.90 & 17.58 \\
\hline 1747 & Gomphotherium angustidens & $13-2$ & -8.74 & -5.63 & 25.11 & 17.64 \\
\hline 1621 & Gomphotherium angustidens & 13-2 & -9.14 & -6.72 & 23.98 & 17.17 \\
\hline 1611 bis & Gomphotherium angustidens & 13-2 & -10.49 & -4.86 & 25.90 & 37.44 \\
\hline
\end{tabular}

rhinoceros, could be due therefore to differences in their gastrointestinal tracts as ruminants have foregut microbial fermentation, whereas horses and rhinoceros are monogastric herbivores.

Anchitherium cf. A. cursor is enriched in the $\mathrm{Ba} / \mathrm{Ca}$ ratio compared to Gomphotherium angustidens. Once more, this difference is observed in all levels. This fact could be indicative of a more browsing habit in the Miocene gomphothere as supported by $\delta^{18} \mathrm{O}_{\mathrm{C} \cdot 3}$ and $\delta^{13} \mathrm{C}_{\mathrm{C} \cdot 3}$ values. On the other hand, the suid Conohyus simorrensis shows a high variability when regarding separate levels. This may be connected to some degree of omnivory.

Additionally, no statistically significant differences were found among stratigraphic levels when species are separately analyzed by means of ANOVA tests (Gomphotherium angustidens: $F=0.146, p=0,865$; Anchitherium cf. A. cursor: $F=0.313, p=0.736$; Conohyus simorrensis:
Table 2 (continued)

\begin{tabular}{|c|c|c|c|c|c|c|}
\hline \multirow[t]{2}{*}{ Sample } & \multirow[t]{2}{*}{ Taxa } & \multirow[t]{2}{*}{ Level } & \multirow{2}{*}{$\frac{\delta^{13} \mathrm{C}_{\mathrm{CO} 3}}{(\%}$} & \multicolumn{2}{|l|}{$\delta^{18} \mathrm{O}_{\mathrm{CO} 3}$} & \multirow{2}{*}{$\frac{\delta^{12} \mathrm{O}_{\mathrm{PO} 4}}{(\%}$} \\
\hline & & & & $\begin{array}{l}\text { (\%。 } \\
\text { VPDB) }\end{array}$ & $\begin{array}{l}\text { (\%o } \\
\text { VSMOW) }\end{array}$ & \\
\hline$\overline{655}$ & Gomphotherium angustidens & T3-2 & -9.95 & -5.87 & 24.86 & 16.57 \\
\hline 2848 & Anchitherium cf. A. cursor & T3-2 & -9.75 & -4.53 & 26.24 & \\
\hline 2157 & Anchitherium cf.A. cussor & T3-2 & -8.93 & -3.93 & 26.85 & 17.87 \\
\hline 2051 & Anchitherium cf.A. cursor & T3-2 & -9.59 & -3.47 & 27.34 & \\
\hline 1714 & Anchitherium cf. A. cursor & T3-2 & -8.96 & -5.67 & 25.06 & 16.53 \\
\hline 1611 & Anchitherium cf.A. cursor & T3-2 & -8.17 & -3.74 & 27.06 & \\
\hline 718 & Anchitherium cf. A. cussor & T3-2 & -12.24 & -6.52 & 24.19 & 17.08 \\
\hline 713 & Anchitherium cf. A. cursor & T3-2 & -12.70 & -6.28 & 24.43 & 16.67 \\
\hline 2162 & Ruminant & T3-2 & -9.90 & -7.94 & 22.72 & \\
\hline 2116 & Ruminant & T3-2 & -8.97 & -2.01 & 26.84 & 16.48 \\
\hline 1725 & Ruminant & T3-2 & -11.29 & -9.57 & 21.04 & \\
\hline 1035 & Ruminant & T3-2 & -9.23 & -5.34 & 25.40 & 16.76 \\
\hline 2120 & Conohyus simorrensis & T3-2 & -6.83 & -6.83 & 23.87 & 16.54 \\
\hline 2938 & Prosantorhinus douvillei & T3-2 & -13.26 & -3.98 & 26.81 & 17.72 \\
\hline 3001 & Gomphotherium angustidens & T3-1 & -9.65 & -5.73 & 25.00 & 19.19 \\
\hline 2969 & Gomphotherium angustidens & T3-1 & -10.29 & -6.87 & 23.83 & 19.44 \\
\hline 2444 & Gomphotherium angustidens & T3-1 & -10.35 & -5.48 & 25.26 & 17.44 \\
\hline 2183 & Gomphotherium angustidens & T3-1 & -13.01 & -5.06 & 25.69 & \\
\hline 1744 & Gomphotherium angustidens & T3-1 & -10.29 & -4.19 & 26.59 & \\
\hline 1189 & Gomphotherium angustidens & T3-1 & -10.04 & -5.23 & 25.52 & 17.12 \\
\hline 1186 & Gomphotherium angustidens & T3-1 & -10.73 & -4.66 & 26.10 & 19.42 \\
\hline 1071 & Gomphotherium ngustidens & T3-1 & -10.72 & -6.03 & 24.69 & 17.22 \\
\hline 3120 & Anchitherium cf. A. cursor & T3-1 & -10.34 & -4.75 & 26.01 & 18.34 \\
\hline 2952 & Anchitherium cf. A. cursor & T3-1 & -10.09 & -4.36 & 26.41 & 17.43 \\
\hline 2816 & Anchitherium cf. A. cursor & T3-1 & -11.22 & -4.66 & 26.10 & 17.65 \\
\hline 2096 & Anchitherium cf. A. cursor & T3-1 & -9.61 & -1.12 & 29.75 & \\
\hline 1179 & Anchitherium cf. A. cursor & T3-1 & -10.37 & -7.03 & 23.66 & \\
\hline 2819 & Ruminant & T3-1 & -10.72 & -4.56 & 26.21 & \\
\hline 2813 & Ruminant & T3-1 & -9.28 & -4.80 & 25.96 & 18.45 \\
\hline 2586 & Ruminant & T3-1 & -9.79 & -4.21 & 26.57 & 19.55 \\
\hline 2453 & Ruminant & T3-1 & -9.28 & 0.62 & 31.55 & 18.79 \\
\hline 2453bis & Ruminant & T3-1 & -8.83 & -4.79 & 25.97 & \\
\hline 2413 & Ruminant & T3-1 & -7.67 & -2.94 & 27.88 & 18.87 \\
\hline 3109 & Conohyus simorrensis & T3-1 & -11.32 & -3.23 & 27.58 & 19.02 \\
\hline ТГ-А* & Gomphotherium angustidens & $\mathrm{T} 1$ & -11.29 & -1.47 & 29.39 & \\
\hline ТГ-B* & Gomphotherium angustidens & $\mathrm{T} 1$ & -10.10 & -1.94 & 28.91 & \\
\hline SS-318 & Anchitherium cf. A. cursor & $\mathrm{T} 1$ & -8.35 & -6.83 & 23.87 & \\
\hline $\begin{array}{c}\text { SOMS-04- } \\
\text { HII }(A)^{*}\end{array}$ & Anchitherium cf. A. cursor & $\mathrm{T} 1$ & -9.90 & -2.05 & 28.80 & \\
\hline SOMS-98* & Anchitherium cf. A. cuisor & $\mathrm{T} 1$ & -10.42 & 0.44 & 31.36 & \\
\hline SS-302 & Ruminant & $\mathrm{T} 1$ & -8.42 & -6.54 & 24.17 & \\
\hline SS-94 & Conohyus simorrensis & $\mathrm{T} 1$ & -10.80 & -8.15 & 22.51 & \\
\hline SS-313 & Conohyus simorrensis & $\mathrm{T} 1$ & -9.01 & -6.24 & 24.48 & \\
\hline
\end{tabular}

Samples with an asterisk are from a previous study by Cuevas-González (2006). The italicized values in the $\delta^{\mathbf{1 2}} \mathrm{O}_{\mathrm{PO} 4}$ column were analyzed in the Servicio General de Análisis de Isótopos Estables (Universidad de Salamanca, Spain), whilst the rest analyzed at Royal Holloway University of London (United Kingdom). The equation $\delta^{12} \mathrm{O}_{\mathrm{CO} 3}(\%$. VSMOW $)=1.03039 \delta^{1 \mathbf{2}} \mathrm{O}_{\mathrm{CO} 3}(\%$ VPDB $)+30.39$ was used to convert VPDB into VSMOW.

$F=2.379, p=0.188$; ruminants: $F=0.168, p=0.851$ ). This indicates that there were not substantial changes in the dietary requirements of the different taxa across the studied Somosaguas section.

\section{Discussion}

The isotopic analyses performed on herbivore tooth enamel from four successive levels of the Somosaguas section reveal a decrease in $\delta^{18} \mathrm{O}$ (carbonate and phosphate), which may reflect a drop in $\delta^{18} \mathrm{O}_{\mathrm{H} 2}$ indicative of a decrease in temperature. A contemporaneous rise in $\delta^{13} \mathrm{C}_{\mathrm{C}}$ values is probably indicative of an increase in aridity.

The temperature decrease across the $\mathrm{T} 3$ level has been estimated at $\sim 6.2 \pm 1.0{ }^{\circ} \mathrm{C}$ (from $17.8^{\circ}$ to $11.6{ }^{\circ} \mathrm{C}$ ) which coincides with the interpretations proposed by other authors for the Mid-Miocene climatic crisis (Frakes et al., 1994; Böhme, 2003; Bentaleb et al., 2006). The temperature decrease along the Somosaguas section could be even greater $\left(\sim 15.0 \pm 1.8{ }^{\circ} \mathrm{C}\right.$, from $26.6^{\circ}$ to $\left.11.6^{\circ} \mathrm{C}\right)$, if we take into account MAT values calculated when using $\delta^{18} \mathrm{O}_{\mathrm{c}}$ values from the lowest T1 level (Hernández Fernández et al., 2006). Although evidence from all the Somosaguas levels indicates a tropical-subtropical 
environment, the difference of around $15{ }^{\circ} \mathrm{C}$ between $\mathrm{T} 1$ and T3-3 is comparable to those found in the largest oscillations between interglacial and glacial periods from different records in the Pleistocene of Europe (Ponel, 1995; Fauquette et al., 1999; Hernández Fernández, 2006; Hernández Fernández et al., 2007). Therefore, it seems that the isotopic record of the mammalian fauna from the Somosaguas sites might reflect a deep change from a warm phase to a temperate phase within the Milankovitch cyclicity typical of the Earth climatic variability. The intensity of this oscillation could be related to

Table 3

$\mathrm{Ba} / \mathrm{Ca}$ ratios of the herbivore tooth enamel analyzed in Somosaguas

\begin{tabular}{|c|c|c|c|c|c|c|c|}
\hline Sample & Taxa & Level & $\mathrm{Ba} / \mathrm{Ca}$ & Sample & Taxa & Level & $\mathrm{Ba} / \mathrm{Ca}$ \\
\hline 3015 & $\begin{array}{l}\text { Gomphotherium } \\
\text { angustidens }\end{array}$ & T3-3 & 0.45 & 655 & $\begin{array}{l}\text { Gomphotherium } \\
\text { angustidens }\end{array}$ & T3-2 & 0.40 \\
\hline 2377 & $\begin{array}{l}\text { Gomphotherium } \\
\text { angustidens }\end{array}$ & T3-3 & 0.57 & 2848 & $\begin{array}{l}\text { Anchitherium cf. } \\
\text { A. cursor }\end{array}$ & T3-2 & 1.32 \\
\hline 2214 & $\begin{array}{l}\text { Gomphotherium } \\
\text { angustidens }\end{array}$ & T3-3 & 0.26 & 2157 & $\begin{array}{l}\text { Anchitherium cf. } \\
\text { A. cursor }\end{array}$ & T3-2 & 0.87 \\
\hline 1562 & $\begin{array}{l}\text { Gomphotherium } \\
\text { angustidens }\end{array}$ & T3-3 & 0.31 & 1714 & $\begin{array}{l}\text { Anchitherium cf. } \\
\text { A. cursor }\end{array}$ & T3-2 & 0.34 \\
\hline 914 & $\begin{array}{l}\text { Gomphotherium } \\
\text { angustidens }\end{array}$ & T3-3 & 0.25 & 1611 & $\begin{array}{l}\text { Anchitherium cf. } \\
\text { A. cursor }\end{array}$ & T3-2 & 0.63 \\
\hline 598 & $\begin{array}{l}\text { Gomphotherium } \\
\text { angustidens }\end{array}$ & T3-3 & 0.25 & 718 & $\begin{array}{l}\text { Anchitherium cf. } \\
\text { A. cursor }\end{array}$ & T3-2 & 0.71 \\
\hline 170 & $\begin{array}{l}\text { Gomphotherium } \\
\text { angustidens }\end{array}$ & T3-3 & 0.27 & 713 & $\begin{array}{l}\text { Anchitherium cf. } \\
\text { A. cursor }\end{array}$ & T3-2 & 0.34 \\
\hline 2890 & $\begin{array}{l}\text { Anchitherium cf. } \\
\text { A. cuisor }\end{array}$ & T3-3 & 0.23 & 2116 & Ruminant & T3-2 & 0.54 \\
\hline 2821 & $\begin{array}{l}\text { Anchitherium cf. } \\
\text { A. cursor }\end{array}$ & T3-3 & 0.46 & 3030 & $\begin{array}{l}\text { Conohyus } \\
\text { simorrensis }\end{array}$ & T3-2 & 0.53 \\
\hline 2474 & $\begin{array}{l}\text { Anchitherium cf. } \\
\text { A. cursor }\end{array}$ & T3-3 & 0.24 & 2938 & $\begin{array}{l}\text { Prosantorhinus } \\
\text { douvillei }\end{array}$ & T3-2 & 0.39 \\
\hline 2348 & $\begin{array}{l}\text { Anchitherium cf. } \\
\text { A. cursor }\end{array}$ & T3-3 & 0.45 & 3001 & $\begin{array}{l}\text { Gomphotherium } \\
\text { angustidens }\end{array}$ & T3-1 & 0.56 \\
\hline 2323 & $\begin{array}{l}\text { Anchitherium cf. } \\
\text { A. cursor }\end{array}$ & T3-3 & 0.57 & 2969 & $\begin{array}{l}\text { Gomphotherium } \\
\text { angustidens }\end{array}$ & T3-1 & 0.50 \\
\hline 2015 & $\begin{array}{l}\text { Anchitherium cf. } \\
\text { A cursor }\end{array}$ & T3-3 & 0.45 & 2444 & $\begin{array}{l}\text { Gomphotherium } \\
\text { angustidens }\end{array}$ & T3-1 & 0.24 \\
\hline 701 & $\begin{array}{l}\text { Anchitherium cf. } \\
\text { A. cursor }\end{array}$ & T3-3 & 1.03 & 2183 & $\begin{array}{l}\text { Gomphotherium } \\
\text { angustidens }\end{array}$ & T3-1 & 0.65 \\
\hline 154 & $\begin{array}{l}\text { Anchitherium cf. } \\
\text { A cursor }\end{array}$ & T3-3 & 1.05 & 1744 & $\begin{array}{l}\text { Gomphotherium } \\
\text { angustidens }\end{array}$ & T3-1 & 0.43 \\
\hline 1077 & Ruminant & T3-3 & 0.62 & 1189 & $\begin{array}{l}\text { Gomphotherium } \\
\text { angustidens }\end{array}$ & T3-1 & 0.39 \\
\hline 623 & Ruminant & T3-3 & 0.90 & 1186 & $\begin{array}{l}\text { Gomphotherium } \\
\text { angustidens }\end{array}$ & T3-1 & 0.24 \\
\hline 2951 & $\begin{array}{l}\text { Conohyus } \\
\text { simorrensis }\end{array}$ & T3-3 & 0.25 & 1071 & $\begin{array}{l}\text { Gomphotherium } \\
\text { angustidens }\end{array}$ & T3-1 & 0.25 \\
\hline 2579 & $\begin{array}{l}\text { Conohyus } \\
\text { simorrensis }\end{array}$ & T3-3 & 0.29 & 3120 & $\begin{array}{l}\text { Anchitherium cf. } \\
\text { A. cursor }\end{array}$ & T3-1 & 0.96 \\
\hline 2357 & $\begin{array}{l}\text { Conohyus } \\
\text { simorrensis }\end{array}$ & T3-3 & 0.55 & 2952 & $\begin{array}{l}\text { Anchitherium cf. } \\
\text { A. cursor }\end{array}$ & T3-1 & 0.30 \\
\hline 635 & $\begin{array}{l}\text { Conohyus } \\
\text { simoriensis }\end{array}$ & T3-3 & 0.34 & 2816 & $\begin{array}{l}\text { Anchitherium cf. } \\
\text { A. cursor }\end{array}$ & T3-1 & 0.69 \\
\hline 146 & $\begin{array}{l}\text { Conohyus } \\
\text { simorrensis }\end{array}$ & T3-3 & 0.26 & 2819 & Ruminant & T3-1 & 0.86 \\
\hline 2991 & $\begin{array}{l}\text { Prosantorhinus } \\
\text { douvillei }\end{array}$ & T3-3 & 0.52 & 2813 & Ruminant & T3-1 & 0.61 \\
\hline 3090 & $\begin{array}{l}\text { Gomphotherium } \\
\text { angustidens }\end{array}$ & T3-2 & 0.37 & 2586 & Ruminant & T3-1 & 0.33 \\
\hline 2912 & $\begin{array}{l}\text { Gomphotherium } \\
\text { angustidens }\end{array}$ & T3-2 & 0.35 & 2453 & Ruminant & T3-1 & 1.70 \\
\hline 2895 & $\begin{array}{l}\text { Gomphotherium } \\
\text { angustidens }\end{array}$ & T3-2 & 0.65 & 3109 & $\begin{array}{l}\text { Conohyus } \\
\text { simorrensis }\end{array}$ & T3-1 & 0.45 \\
\hline 2867 & $\begin{array}{l}\text { Gomphotherium } \\
\text { angustidens }\end{array}$ & T3-2 & 0.38 & SS-318 & $\begin{array}{l}\text { Anchitherium cf. } \\
\text { A. cursor }\end{array}$ & $\mathrm{T} 1$ & 0.26 \\
\hline 1747 & $\begin{array}{l}\text { Gomphotherium } \\
\text { angustidens }\end{array}$ & T3-2 & 0.65 & SS-302 & Ruminant & $\mathrm{T} 1$ & 0.40 \\
\hline 1621 & $\begin{array}{l}\text { Gomphotherium } \\
\text { angustidens }\end{array}$ & T3-2 & 0.36 & SS-312 & $\begin{array}{l}\text { Conohyus } \\
\text { simorrensis }\end{array}$ & $\mathrm{T} 1$ & 0.24 \\
\hline $\begin{array}{l}1611 \\
\text { bis }\end{array}$ & $\begin{array}{l}\text { Gomphotherium } \\
\text { angustidens }\end{array}$ & T3-2 & 0.45 & SS-313 & $\begin{array}{l}\text { Conohyus } \\
\text { simorrensis }\end{array}$ & $\mathrm{T} 1$ & 0.28 \\
\hline
\end{tabular}

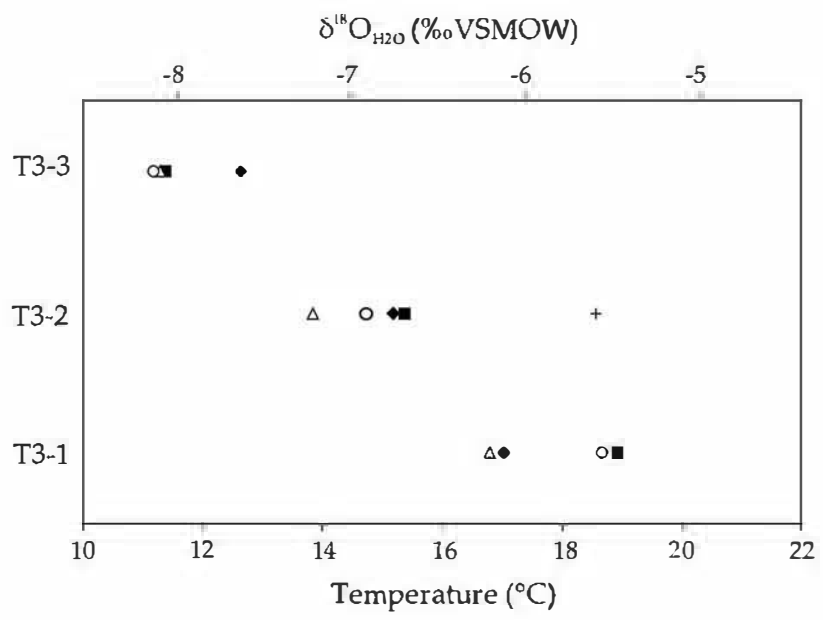

Fig. 9. Evolution of $\boldsymbol{\delta}^{\mathbf{1 2}} \mathrm{O}_{\mathrm{H} 2 \mathrm{O}}$ mean values (\%.VSMOW) from T3-1 to T3-3 calculated by using the Eqs. (1)-(5) proposed by Tütken et al. (2006) (see text) and mean annual temperature (MAT) values $\left({ }^{\circ} \mathrm{C}\right)$ calculated by using Yurtsever and Gat (1981)'s equation (6 in text). Black square: Gomphotherium angustidens, white triangle: Anchitherium cf. A cursor, black diamond: ruminant, white circle: Conohyus simorrensis, cross: Prosantorhinus douvillei. Standard deviation is $<3 \%$ in all cases.

the enhancement of the Middle Miocene global cooling trend $14 \mathrm{Ma}$ ago (Flower, 1999; Shevenell et al., 2004). Moreover, Cuevas-González (2006) and Hernández Fernández et al. (2006) reported a decrease in $\delta^{18} \mathrm{O}_{\mathrm{C} \bullet}$ values of paleosoil carbonates from the Somosaguas site that indicates a general drop in MATs of around $14{ }^{\circ} \mathrm{C}$, which supports the magnitude of the cooling pinpointed in the oxygen isotopic values from the mammalian dental enamel. Nevertheless, future $\delta^{18} \mathrm{O}_{\mathrm{P}}$ analyses on enamel from $\mathrm{T} 1$, should be performed in order to corroborate this larger magnitude cooling event.

These findings support the general pattern of global cooling and increased aridity observed by different authors in marine and continental sections from this period (Sarnthein et al., 1982; Kennett and Barker, 1990; van der Meulen and Daams, 1992; Zachos et al., 2001; Hernández Fernández et al., 2003; Cuevas-González, 2005; Fesharaki, 2005). As previously said, Lower and Middle Units in the Madrid Basin showverylow sedimentation rates, so that a time span of $\sim 105-125 \mathrm{ka}$ can be estimated from $\mathrm{T} 1$ to T3-3. Therefore, the palaeoclimatic record

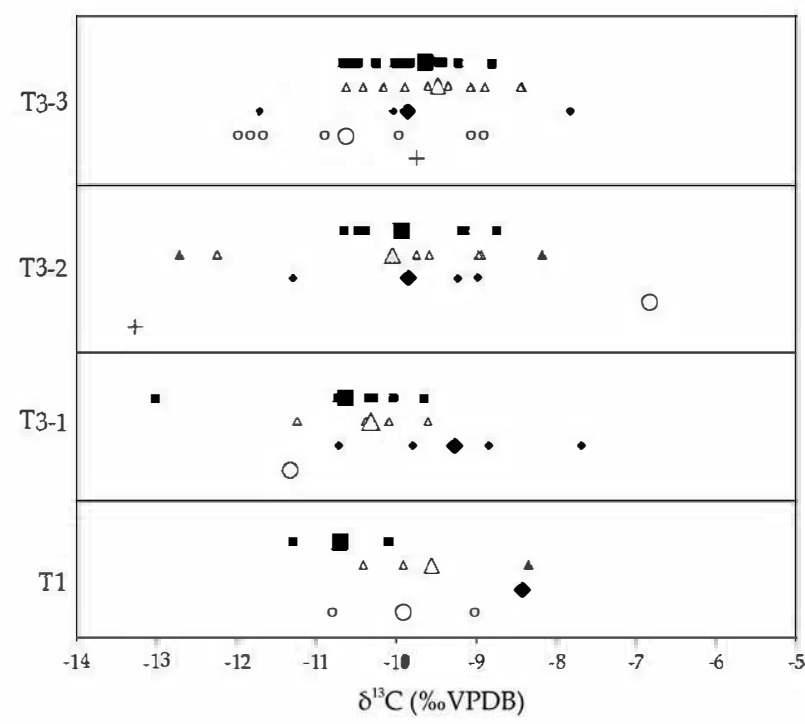

Fig. 10. Evolution of $\boldsymbol{8}^{13} \mathrm{C}_{\mathrm{CO}}$ values (\%.VPDB) from $\mathrm{T} 1$ to T3-3. Black square: Gom photherium angustidens, white triangle: Anchitherium cf, A. cursor, black diamond ruminant, white circle: Conohyus simorrensis, cross: Prosantorhinus douviliei. Larger symbols represent the mean isotopic value. 


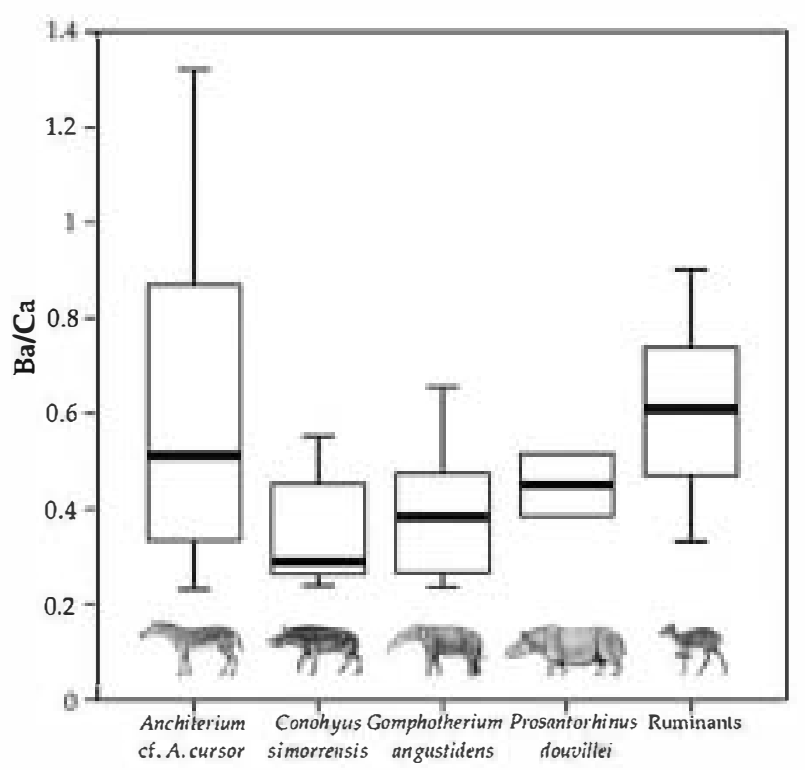

Fig. 11. Box and whisker plots for enamel Ba/Ca ratios of Anchitherium cf. A. cursor, Conohyus simorrensis, Gomphotherium angustidens, Prosantorhinus douvillei and ruminants from all levels at Somosaguas site. Boxes are bounded by the 25th and 75th percentiles and bisected by the 50th percentile (median). The lines are drawn out to the 10 th and 90 th percentiles. Mammal reconstructions by Sergio Pérez, not to scale.

across the Somosaguas sections is coincident with the sudden global cooling detected in oceans and continents from high and middle latitudes about $14 \mathrm{Ma}$ ago, attributed to the reestablishment of the Antarctica ice cap (Flower and Kennett, 1994; Zachos et al., 2001; Shevenell et al., 2004). This event brought about a global and sudden ( $200 \mathrm{ka}$; Zachos et al., 2001) decrease in temperatures, as reflected in the increase of $\delta^{18} \mathrm{O}$ in planktonic and benthic foraminifera. This event was also accompanied by a sea level fall, profound changes in the deep ocean circulation, a positive ${ }^{13} \mathrm{C}$ excursion (Monterey Event) and increasing aridity in mid-latitude areas.

Most studies related to this cooling episode have been focused on the marine record (Shackleton and Kennett, 1975; Miller and Katz, 1987; Woodruff and Savin, 1991; Abreu and Anderson, 1998; Pagani et al., 2000; Billups and Schrag, 2002). Less attention has traditionally been paid to the terrestrial record, but it has been observed that the response to this global cooling happened a little later between 14 and 13.5 Ma in the continental realm (Böhme, 2003; Bruch et al., 2007), coincident with the age of the Somosaguas section. Frakes et al. (1994) produced a compilation of palaeotemperature values based on terrestrial proxies and developed temperature curves for particular latitudes and ages from the Early Cretaceous to the Middle Miocene. These authors detected a decrease in the temperature value at $\sim 14 \mathrm{Ma}$. For a palaeolatitude of $40^{\circ} \mathrm{N}$ (similar to the Somosaguas latitude at that moment), the temperature value estimated by Frakes et al. (1994) is $\sim 15-20{ }^{\circ} \mathrm{C}$. Böhme (2003) carried out a further palaeoclimatic study based upon ectothermicvertebrates assemblages from Central Europe and proposed a pattern of change for MAT from the Early to the Late Miocene. According to this author, a sudden climatic shift took place between 14 and 13.5 Ma giving rise to the extinction of alligators, chameleons and giant turtles in this area. This climatic shift is represented by a MAT drop of at least $7{ }^{\circ} \mathrm{C}$ to minimum values around $15{ }^{\circ} \mathrm{C}$.

Concerning the increase in ${ }^{13} \mathrm{C}_{\mathrm{C} \cdot 3}$ values from mammal dental enamel from the Somosaguas section, a trend towards increased aridity can be deduced. According to Feranec and MacFadden (2006) and Kohn and Law (2006), in $\mathrm{C}_{3}$-dominated ecosystems (either modern ecosystems lacking $C_{4}$ plants or ancient ecosystems previous to $C_{4}$ plants expansion at the Late Miocene-Pliocene boundary), the $\delta^{13}$ Cvalues from palaeosoils or vertebrate bones and enamel correlate to the precipitation amount and plant productivity and with the ratio between potential evapotranspiration and mean annual precipitation. Thus, low $\delta^{13} \mathrm{C}$ values indicate wetter conditions, whilst high $\delta^{13} \mathrm{C}$ values may reflect drier conditions, according to these authors. The increase in $\delta^{13} \mathrm{C}_{\mathrm{c}}$ values observed from T3-1 to T3-3 in the two most abundant taxa at the Somosaguas site (Gomphotherium angustidens and Anchitherium cf. A. cursor) would therefore indicate a shift towards more arid conditions.

This aridity trend in Somosaguas is compatible with van der Meulen and Daams (1992)'s study carried out in the Calatayud-Daroca Basin (Spain). As commented above, they located an aridity peak in Biozone E, which is coincident with the dating of the Somosaguas site. This increase in the aridity patterns has also been observed in other mid-latitude regions all around the world, such as Africa (Retallack, 1992), North America (Wolfe, 1985), South America (Pascual and Ortiz-Jaureguizar, 1990) and Australia (Stein and Robert, 1986). LópezMartínez et al. (2000) argued that the arid period recorded in the Madrid Basin corresponds to a cooling event detected in high latitude oceans and continents approximately $14 \mathrm{Ma}$ ago (see above).

On the other hand, it is noticeable that although the isotopic signal recorded in mammal enamel from Somosaguas shows a clear correspondence with the changes in the environmental conditions detected in the Middle Miocene, $\mathrm{Ba} / \mathrm{Ca}$ analyses do not record any well defined pattern of change from $\mathrm{T} 1$ to $\mathrm{T} 3-3$, demonstrating that the dietary requirements from the studied taxa were maintained. This is probably related to the larger dietary versatility of herbivores living in arid environments (Sinclair, 2000).

It is also interesting to note that the $6{ }^{\circ} \mathrm{C}$ decrease from T3-1 to T3-3 had no relevance in the faunal composition of the mammalian fauna in T3. Within the tropical realm, it is usual that relatively large changes in climatic factors associated to temperature are not paralleled with significant changes in faunal composition. This is because in such ecosystems, temperature is not the limiting factor for mammalian faunas. Instead, changes in humidity are much more important for tropical faunas. Nevertheless, the increase in aridity from T3-1 to T3-3 is not apparently reflected in the composition of the mammalian community of Somosaguas. This could be related to the fact that faunas inhabiting arid ecosystems are usually adapted to the high degrees of variation in precipitations in these areas (Walter and Breckle, 1986; Schultz, 2005) and, therefore, changes in aridity larger than the one observed here are needed in order to detect faunal changes. After this important palaeoclimatic shift, the same or very similar vertebrate species continued to inhabit the Madrid Basin in Late Aragonian times (Soria et al., 2000), which suggest no major evolutionary change in the mammalian fauna at this key climatic interval.

\section{Conclusions}

This study provides palaeoenvironmental information by means of geochemical analyses of dental enamel from different herbivore mammals (Gomphotherium angustidens, Anchitherium cf. A. cursor, Conohyus simorrensis, Prosantorhinus douvillei and ruminants) from the Somosaguas site (Madrid Basin, Spain) dated to the Middle Miocene (Middle Aragonian Biozone E; 14.1-13.8 Ma). Previous Scanning Electron Microscope and Rare Earth Element analyses suggested only minor alteration of the dental enamel from this site. $\delta^{18} \mathrm{O}_{\mathrm{C} \bullet 3}$ and $\delta^{18} \mathrm{O}_{\mathrm{P}} 4$ values showed a decrease across the stratigraphic succession, related to a drop in the $\delta^{18} \mathrm{O}_{\mathrm{H} 2 \bullet}$, which in turn is connected with a decrease of MATs. From level T3-1 to T3-3, in less than $100 \mathrm{ka}$, a drop of $\sim 2.4 \pm 0.4 \%$ (VSMOW) in $\delta^{18} \mathrm{O}_{\mathrm{H} 2}$ is recorded, that would correspond to a drop of $\sim 6.2 \pm 1.0^{\circ} \mathrm{C}$ in MAT, from $17.8{ }^{\circ} \mathrm{C}$ to $11.6{ }^{\circ} \mathrm{C}$. These values agree well with those proposed by other authors in continental studies for this period of time and coincide with the global, rapid climatic shift detected in the oceans at Middle Miocene times, when the Miocene Climatic Optimum was followed by a sudden deterioration of the climate as a consequence 
of the reestablishment of the ice cap in Antarctica. Moreover, Somosaguas section also records an increase of $\delta^{13} \mathrm{C}_{\mathrm{C} \bullet 3}$ values, indicating an increase in aridity. This confirms the intense aridification in middle latitudes that accompanied the Middle Miocene global cooling.

Aditionally, ${ }^{13} \mathrm{C}_{\mathrm{C}}$ values were also indicative of the dietary habits of Somosaguas mammals, which are coherent with those provided by $C_{3}$ feeders (since $C_{4}$ plants were only abundant from the Late Miocene-Early Pliocene). However, it has been possible to infer a less browsing habit for Anchitherium of. A. cursor and the ruminants. Finally, $\mathrm{Ba} / \mathrm{Ca}$ ratios also suggest a higher percentage of forbs in the diet of the equid compared to the gomphothere, as well as differences between gastrointestinal tracts (ruminants vs. equid, gomphothere and rhino) and a more omnivorous behaviour for the suid Conohyus simorrensis. The fact that $\mathrm{Ba} / \mathrm{Ca}$ patterns did not show any significant difference across different levels might be indicative of the maintenance of the dietary behaviour in spite of the detected shift in past climatic and environmental conditions.

Therefore, it has been shown that the Somosaguas site (Madrid Basin, Spain) is an excellent succession with the right age and fossil content to study the effects of the Middle Miocene global cooling in continental palaeoenvironments. Further investigations on this and other Middle Miocene mammalian palaeontological sites may help to gain a thorough understanding of the effects that this global event exerted on the continental ecosystems.

\section{Acknowledgments}

This research was supported by the UCM and the Spanish Ministerio de Educación y Ciencia (Plan Nacional I+D, project CGL2006-04646 to N.L.M. and a FPU predoctoral contract to LD.). The work conducted by S.T.G. was supported by a Natural Environmental Research Council (NERC) New Investigators grant (NE/ C507237/1). M.H.F. was funded by the MEC through the Programa Ramón y Cajal (UCM contract) and the Plan Nacional I+D (project CGL2006-01773/BTE). Authors are grateful to C. Recio and A. Martín Monge (Servicio General de Análisis de Isótopos Estables, Universidad de Salamanca) and N. Grassineau and D. Lowry (Royal Holloway University of London) for their help with the isotopic analyses. We thank M. Bugler (University of Plymouth) for her help with the sample preparation. S. Domingo (Museo Nacional de Ciencias Naturales-CSIC, Madrid) and A. Martín Monge (Universidad de Salamanca) are acknowledged for their valuable comments that substantially improved the manuscript. S. Pérez (Universidad Complutense de Madrid) kindly provided the drawings for the studied species. The recovery and study of the fossil material was done by the members of the Somosaguas Palaeontological Project (http://www.ucm.es/info/ somosagu/) in collaboration with numerous students of the UCM (http://investigacionensomosaguas.blogspot.com). This work is a contribution from the research groups UCM-CAM 910161 on Geologic Record of Critical Periods: Palaeoclimatic and Palaeonvironmental Factors, and UCM-CAM 910607 on Evolution of Cenozoic Mammals and Continental Palaeoenvironments. Finally, we acknowledge editors F. Surlyk and F. Kop and reviewers M. T. Alberdi (Museo Nacional de Ciencias Naturales-CSIC, Madrid) and D. L. Fox (University of Minnesota) for their useful comments and suggestions that helped to greatly improve the final version of this manuscript.

\section{References}

Abreu, V.S., Anderson, J.B., 1998. Glacial eustasy during the Cenozoic: sequence stratigraphic implications. AAPG Bulletin 82, 1385-1400.

Alberdi, M.T. (Coord.), 1985. Geología y Paleontología del Terciario continental de la provincia de Madrid. Conse jo Superior de Investigaciones Científicas. MNCN 1-105. Amezua, L., Salesa, M.J., Pérez, B., Peláez-Campomanes, P., Fraile, S., Morales, J., Nieto, M., 2000. Paleoecología In: Morales,J. (Coord.): Patrimonio paleontológico de la Comunidad de Madrid, Conse jería de Educación de la Comunidad de Madrid, pp. 155-172.
Amiot, R., lécuyer, C., Escarguel, G., Billon-Bruyat, J.-P., Buffetaut, E., Langlois, C., Martin, S. Martineau, F., Mazin, J.-M., 2007. Oxygen isotope fractionation between crocodilian phosphate and water. Palaeogeography, Palaeoclimatology, Palaeoeoology 243, 412-420

Ayliffe, L.K., Lister, A.M., Chivas, A.R., 1992. The preservation of glacial-interglacial climatic signatures in the oxygen isotopes of elephant skeletal phosphate. Palaeogeography, Palaeoclimatology, Palaeoecology 99, 179-191.

Balter, V., lécuyer, C., 2004. Determination of Sr and Ba partition coefficients between apatite and water from $5^{\circ} \mathrm{C}$ to $60^{\circ} \mathrm{C}$ : a potential new thermomether for aquatic paleoenvironments. Geochimica et Cosmochimica Acta 68, 423-432.

Balter, V., Bocherens, H., Person, A., Labourdette, N., Renard, M., Vandermeersch, B., 2002. Ecological and physiological variability of $\mathrm{Sr} / \mathrm{Ca}$ and $\mathrm{Ba} / \mathrm{Ca}$ in mammals of West European mid-Würmian food webs. Palaeogeography, Palaeoclimatology, Palaeoecology 186, 127-143.

Bender,M.M., 1971. Variations in the ${ }^{13} \mathrm{C} /{ }^{12} \mathrm{C}$ ratios of plants in relation to the pathway of photosynthetic carbon dioxide fixation. Phytochemistry $10,1239-1245$

Bentaleb, I., Langlois, C, Martin, C., Iacumin, P., Carre, M., Antoine, P.-O., Duranthon, F., Moussa, I.,Jaeger,J.-J., Barrett, N., Kandorp, R., 2006. Rhinocerotid tooth enamel ${ }^{18} \mathrm{O} /$ ${ }^{16} \mathrm{O}$ variability between 23 and $12 \mathrm{Ma}$ in southwestern France. Comptes Rendus Geosciences 338, 172-179.

Billups, K., Schrag, D.P., 2002. Paleotemperatures and ice volume of the past $27 \mathrm{Myr}$ revisited with paired $\mathrm{Mg} / \mathrm{Ca}$ and ${ }^{18} \mathrm{O} /{ }^{16} \mathrm{O}$ measurements in benthic foraminifera Paleoceanography $17,3(1)-3(11)$.

Blum, J.D., Taliaferro, H., Weisse, M.T., Holmes, R.T., 2000. Changes in Sr/Ca, Ba/Ca and ${ }^{87} \mathrm{Sr} /{ }^{86} \mathrm{Sr}$ ratios between trophic levels in two forest ecosystems in the northeastern USA. Biogeochemistry 49, 87-101.

Bocherens, H., Koch, P.L., Mariotti, A., Geraads, D., Jaeger, J.-J., 1996. Isotopic biogeochemistry $\left({ }^{13} \mathrm{C},{ }^{12} \mathrm{O}\right)$ of mammalian enamel from African Pleistocene hominid sites. Palaios $11,306-318$.

Böhme, M., 2003. The Miocene Climatic Optimum: evidence from ectothermic vertebrates of Central Europe. Palaeogeography, Palaeoclimatology, Palaeoecology 195, 389-401.

Bruch, A.A., Uhl, D., Mosbrugger, V., 2007. Miocene climate in Europe - patterns and evolution: a first synthesis of NECLIME. Palaeogeography, Palaeoclimatology, Palaeoecology 253, 1-7.

Bryant,J.D., 1995. Oxygen isotope systematics in mammalian body water and in modern and fossil equid tooth enamel phosphate. Ph.D. thesis. Columbia University.

Bryant, J.D., Froelich, P.N., 1995. A model of oxygen isotope fractionation in body water of large mammals. Geochimica et Cosmochimica Acta 59, 4523-4537.

Bryant, J.D., Froelich, P.N., Showers, W.J., Genna, B.J., 1996. A tale of two quarries: biologic and taphonomic signatures in the oxygen isotope composition of tooth enamel phosphate from modern and Miocene equids. Palaios 11, 397-408.

Burton,J.H., Price, T.D., Middleton, W.D., 1999. Correlation of bone Ba/Ca and Sr/Ca due to biological purification of calcium. Journal of Archaeological Science 26, 609-616.

Calvo, J.P., 1989. Terciario. In: Pérez-González, A., Calvo, J.P. (Eds.), Memoria de la Hoja Geológica 1:50.000, Madrid, $n^{\bullet}$ 559. IGME, Madrid, pp. 9-45.

Calvo, J.P.,Daams, R., Morales, J., Iópez-Martínez, N., Agustí, J., Anadón, P., Armenteros, I. Cabrera, L., Civis, J., Corrochano, A., Díaz Molina, M., Elizaga, E., Hoyos, M., MartínSuárez, E., Martínez,J., Moissenet, E., Muñoz, A., Pérez García,A., Pérez-González, A. Portero, J.M., Robles, F., Santisteban, C, Torres, T., van der Meulen, A.J., Vera, J.A. Mein, P., 1993. Up-to-date Spanish continental Neogene synthesis and paleoclimatic interpretation. Revista de la Sociedad Geológica de España 6, 29-40.

Cande, S.C., Kent, D.V., 1995. Revised calibration of the geomagnetic polarity timescale for the Late Cretaceous and Cenozoic. Journal of Geophysical Research 100, 6093-6095.

Carrasco, A., Sacristán, S., Benítez-López, G., Romero-Nieto, D., Fesharaki, O., Iópez Martínez, N., 2008. Aplicaciones paleoclimáticas y paleoambientales de los estudios mineralógicos al yacimiento de vertebrados miocenos de Somosaguas. Seminario de Paleontología de Zaragoza 8, 135-149.

Cerdeño, E., 1989. Revisión de la sistemática de los rinocerontes del Neógeno de España Colec. Tes. Doct. Univ. Complutense Madrid, 429 pp.

Cerling, T.E., Harris, J.M., 1999. Carbon isotope fractionation between diet and bioapatite in ungulate mammals and implications for ecological and paleoecological studies. Oecologia 120, 347-363.

Costeur, L, Iegendre, S., 2008. Mammalian communities document a latitudinal environmental gradient during the Miocene Climatic Optimum in Western Europe Palaios 23, 280-288.

Cuevas-González, J., 2005. Estado actual de los conocimientos paleontológicos y estratigráficos de los yacimientos aragonienses de Somosaguas (Pozuelo de Alarcón, Madrid). Coloquios de Paleontología 55, 103-123.

Cuevas-González, J., 2006. Estudio isotópico de $\delta^{13} \mathrm{Cy} \delta^{12} \mathrm{O}$ en sedimentos y fósiles de los yacimientos de Somosaguas del Mioceno Medio (Cuenca de Madrid). Trabajo de investigación para la obtención del Diploma de Estudios Avanzados (DEA) Universidad Complutense de Madrid. $31 \mathrm{pp}$.

D'Angela, D., Longinelli, A., 1990. Oxygen isotopes in living mammal's bone phosphate: Further results. Chemical Geology 86, 75-82.

Daams, R., Freudenthal, M., van de Weerd, A., 1977. Aragonian, a new stage for continental deposits of Miocene age. Newsletters on Stratigraphy 6, 42-55.

Daams, R., vander Meulen, A.J., Álvarez Sierra, M.Á.,Peláez-Campomanes, P., Krijgsman, W., 1999. Aragonian stratigraphy reconsidered, and a re-evaluation of the Middle Miocene mammal biochronology in Europe. Earth and Planetary Science Letters 165, 287-294

Dettman, D.L., Kohn, M.J., Quade, J., Kyerson, F.J., Ojha, T.P., Hamidullah, S., 2001 Seasonal stable isotope evidence for a strong Asian monsoon throughout the past 10.7 m.y. Geology 29, 31-34.

Ehleringer, J.R., Sage, R.F., Flanagan, L.B., Pearcy, R.W., 1991. Climate change and the evolution of $C_{4}$ photosynthesis. Trends in Ecology and Evolution 6, 95-99.

Elez, J., 2005. Aplicación GIS 3D a los yacimientos paleontológicos de Somosaguas Trabajo de investigación para la obtención del Diploma de Estudios Avanzados (DEA). Universidad Complutense de Madrid. 39 pp. 
Elias, R.W. Hirao, Y., Patterson, C.C., 1982. The circumvention of the natural biopurification of calcium along nutrient pathways by atmospheric inputs of industrial lead. Geochimica et Cosmochimica Acta 46, 2561-2580.

Elorza,J.,Astibia, H., Murelaga, X., Pereda-Suberbiola, X., 1999. Francolite as adiagenetic mineral in dinosaur and other Upper Cretaceous reptile bones (Laño, Iberian Peninsula): microstructural, petrological and geochemical features. Cretaceous Research 20, 169-187.

Farquhar, G.D., Ehleringer, J.R., Hubick, K.T., 1989. Carbon isotopic discrimination and photosynthesis. Annual Reviews of Plant Physiology and Plant Molecular Biology $40,503-537$.

Fauquette, S., Guiot, J., Menut, M., de Beaulieu, J.-L., Reille, M., Guenet, P., 1999 Vegetation and climate since the last interlacial in the Vienne area (France). Global and Planetary Change 20,1-17

Feranec, R.S., MacFadden, B.J., 2006. Isotopic discrimination of resource partitioning among ungulates in $\mathrm{C}_{3}$-dominated communities from the Miocene of Florida and California. Paleobiology 32, 191-205.

Fesharaki, O., 2005. Mineralogía y sedimentología del yacimiento paleontológico de Somosaguas (Mioceno, Cuenca de Madrid). Trabajo de investigación para la obtención del Diploma de Estudios Avanzados (DEA). Universidad Complutense de Madrid. $147 \mathrm{pp}$

Flower, P., 1999. Palaeoclimatology: warming without high $\mathrm{CO}_{2}$. Nature 399, 313-314.

Flower, B.P. Kennett, J.P. 1994. The middle Miocene climatic transition: East Antarticice sheet development, deep ocean circulation and global carbon cycling. Palaeogeography, Palaeoclimatology, Palaeoecology 108, 537-555.

Fox, D.L., Fisher, D.C., 2004. Dietary reconstruction of Miocene Gomphotherium (Mammalia, Proboscidea) from the Great Plains region, USA, based on the carbon isotope composition of tusk and molar enamel. Palaeogeography, Palaeoclimatol ogy, Palaeoecology 206, 311-335.

Fraile, S., Amezua, L., Morales, J., Nieto, M., Peláez-Campomanes, P., Salesa, M.J., Sánchez LM., 2000. Marco general del Terciario. In: Morales, J. (Coord.), Patrimonio paleontológico de la Comunidad de Madrid. Consejería de Educación de la Comunidad de Madrid, pp. 85-101.

Frakes, L.A., Probst, J.-L., Ludwig, W., 1994. Latitudinal distribution of paleotemperature on land and sea from early Cretaceous to middle Miocene. Comptes rendus de l'Académie des Sciences. Paris 318, 1209-1218.

Fricke, H.C., O'Neil, J.R., 1996. Inter- and intra-tooth variation in the oxygen isotope composition of mammalian tooth enamel phosphate: implications for palaeoclimatological and palaeobiological research. Palaeogeography, Palaeoclimatology Palaeoecology 126, 91-99.

Fricke, H.C., Clyde, W.C., O'Neil, J.R., 1998. Intra-tooth variations in $\delta^{\mathbf{1 8}} \mathrm{O}_{\mathrm{PO}}$ of mammalian tooth enamel as a record of seasonal variations in continental climate variables. Geochimica et Cosmochimica Acta 62, 1839-1850

Gilbert, C, Sealy, J., Sillen, A., 1994. An investigation of barium, calcium and strontium as palaeodietary indicators in the Southwestern Cape, South Africa. Journal of Archaeological Science 21, 173-184.

Grimes, S.T., Hooker, J.J., Collinson, M.E., Mattey, D.P., 2005. Summer temperatures of late Eocene to early Oligocene freshwaters. Geology 33, 189-192.

Grimes, S.T., Mattey, D.P., Collinson, M.E., Hooker, J.J., 2004. Using mammal tooth phosphate with freshwater carbonate and phosphate paleoproxies to obtain mean temperatures. Quaternary Science Reviews 23, 967-976.

Grimes, S.T., Mattey, D.P., Hooker, J.J., Collinson, M.E., 2003. Paleogene paleoclimate reconstruction using oxygen isotopes from land and freshwater organisms: the use of multiple paleoproxies. Geochimica et Cosmochimica Acta 67 4033-4047.

Hernández Fernández, M., 2006. Rodent paleofaunas as indicators of climatic change in Europe during the last 125,000 years. Quaternary Research 65, 308-323.

Hernández Fernández, M, Álvarez Sierra, MÁ, Peláez-Campomanes, P. 2007. Bioclimatic analysis of rodent palaeofaunas reveals severe climatic changes in Southwestern Europe during the Plio-Pleistocene. Palaeogeography, Palaeoclimatology, Palaeoecology 251, 500-526.

Hernández Fernández, M., Cárdaba, J.A., Cuevas-González, J., Fesharaki, O., Salesa, M. Corrales, B., Domingo, L., Elez, J., López Guerrero, P., Sala-Burgos, N., Morales, J. López Martínez, N., 2006. Los yacimientos de vertebrados del Mioceno medio de Somosaguas (Pozuelo de Alarcón, Madrid): implicaciones paleoambientales y paleoclimáticas. Estudios Geológicos 62, 263-294.

Hernández Fernández, M., Salesa, M.J., Sánchez, LM., Morales,J., 2003. Paleoecología de género Anchitherium von Meyer, 1834 (Equidae, Perissodactyla, Mammalia) en España: evidencias a partir de las faunas de macromamíferos. Coloquios de Paleontología 1, 253-280 voL ext.

Hubert, J.F., Panish, P.T., Chure, D.J., Prostak, K.S., 1996. Chemistry, microstructure, petrology, and diagenetic model of Jurassic dinosaur bones, Dinosaur National Monument, Utah. Journal of Sedimentary Research 66, 531-547.

Huertas, A.D., Iacumin, P., Stenni, B., Chillón, B.S., Longinelli, A., 1995. Oxygen isotope variations of phosphate in mammalian bone and tooth enamel. Geochimica et Cosmochimica Acta 59, 4299-4305.

Iacumin, P., Bocherens, H., Mariotti, A., Ionginelli, A., 1996. Oxygen isotope analyses of coexisting carbonate and phosphate in biogenic apatite: a way to monitor diagenetic alteration of bone phosphate? Earth and Planetary Science letters 142, 1-6.

Jiménez-Moreno, G., Suc, J.-P., 2007. Middle Miocene latitudinal climatic gradient in Western Europe: evidence from pollen records. Palaeogeography, Palaeoclimatology, Palaeoecology 253, 208-225.

Kennett, J.P., Barker, P.F., 1990. Latest Cretaceous to Cenozoic climate and oceanographic developments in the Weddell Sea, Antarctica: an ocean-drilling perspective. In Barker, P.F., Kennett, J.P., et aL (Eds.), Proc. ODPSci. Res., voL 113, pp. 937-960.

Kohn, M.J., 1996. Predicting animal $\delta^{12} \mathrm{O}$ : accounting for diet and physiological adaptation. Geochimica et Cosmochimica Acta 60, 4811-4829.
Kohn, M.J., Law, J.M., 2006. Stable isotope chemistry of fossil bone as a new paleoclimate indicator. Geochimica et Cosmochimica Acta 70, 931-946.

Kolodny, Y., Raab, M., 1988. Oxygen isotope in phosphatic fish remains from Israel: paleothermometry of tropical Cretaceous and Tertiary shelf waters. Palaeogeography, Palaeoclimatology, Palaeoecology 64, 59-67.

Kolodny, Y., Luz, B., Sander, M., Clemens, W.A., 1996. Dinosaur bones: fossils or pseudomorphs? The pitfalls of physiology reconstruction from apatitic fossils. Palaeogeography, Palaeoclimatology, Palaeoecology 126, 161-171.

Kürschner, W.M., Kvacek, Z., Dilcher, D.L., 2008. The impact of Miocene atmospheric carbon dioxide fluctuations on climate and the evolution of terrestrial ecosystems. Proceedings of the National Academy of Sciences 105, 449-453.

Latorre, C., Quade, J., Mclntosh, W.C, 1997. The expansion of $C_{4}$ grasses and global change in the late Miocene: Stable isotope evidence from the Americas. Earth and Planetary Science Letters 146, 83-96.

lécuyer, C., Grand jean, P., Paris, F., Robardet, M., Robineau, D., 1996. Deciphering "temperature" and "salinity" from biogenic phosphates: the $\delta^{\mathbf{1 2}} \mathrm{O}$ of coexisting fishes and mammals of the Middle Miocene sea of western France. Palaeogeography, Palaeoclimatology, Palaeoecology 126, 61-74.

Lécuyer, C., Picard, S., Garcia, J.-P., Sheppard, S.M.F., Grandjean, P., Dromart, G., 2003a Thermal evolution of Tethyan surface waters during the Middle-Late Jurassic: Evidence from $\boldsymbol{\delta}^{\mathbf{1 2}} \mathrm{O}$ values of marine fish teeth. Paleoceanography $18,21(1)-21$ (16).

Iécuyer, C., Bogey, C., Garcia, J.-P., Grand jean, P., Barrat, J.-A., Floquet, M., Bardet, N., Pereda-Suberbiola, X., 2003b. Stable isotope composition and rare earth element content of vetebrate remains from the Late Cretaceous of northern Spain (Laño): did the environmental record survive? Palaeogeography, Palaeoclimatology, Palaeoe cology 193, 457-471.

Iee-Thorp, J.A., Sponheimer, M., 2003. Three case studies used to reassess the reliability of fossil bone and enamel isotope signals for paleodietary studies. Journal of Anthropological Archaeology 22, 208-216.

LeGeros, R.Z., 1981. Apatites in biological systems. Progress in Crystal Growth and Characterization $4,1-45$.

legget, R.W., 1992. Fractional absorption of ingested barium in adult humans. Health Physics 62, 556-561.

Ievin, N.E., Cerling, T.E., Passey, B.H., Harris, J.M., Ehleringer, J.R., 2006. A stable isotope aridity index for terrestrial environments. Proceedings of the National Academy of Sciences 103, 11201-11205.

Lewis, A.R., Marchant, D.R., Ashworth, A.C., Hedenäs, L., Hemming, S.R., Johnson, J.V., Leng, M.J., Machlus, M.L, Newton, A.E., Raine, J.L, Willenbring, J.K., Williams, M., Wolfe, A.P., 2008. Mid-Miocene cooling and the extinction of tundra in continental Antarctica. Proceedings of the National Academy of Sciences 105 , 10676-10680.

Lindars, E.S., 1998. Oxygen isotope microanalysis of biogenic phosphates by laserfluorination and its application for palaeothermometry in Eocene freshwater systems. Ph.D. thesis. Royal Holloway. University of London.

Lindars, E.S., Grimes, S.T., Mattey, D.P., Collinson, M.E., Hooker, J.J., Jones, T.P., 2001 Phosphate $\delta^{\mathbf{1 2}} \mathrm{O}$ determination of modern rodent teeth by direct laser fluorination: an appraisal of methodology and potential application to palaeoclimate reconstruction. Geochimica et Cosmochimica Acta 65, 2535-2548.

Ionginelli, A., 1984. Oxygen isotopes in mammal bone phosphate: a new tool for paleohydrological and paleoclimatological research? Geochimica et Cosmochimica Acta 48, 385-390.

Iópez-Martínez, N., Elez, J., Hernando, J.M., Luis, A., Mazo, A., Mínguez-Gandú, D., Morales, Polonio, I., Salesa, J.M., Sánchez, LM., 2000. Los vertebrados fósiles de Somosaguas (Pozuelo, Madrid). Coloquios de Paleontología 51, 69-86.

Luis, A., Hernando, J.M., 2000. Los microvertebrados fósiles del Mioceno Medio de Somosaguas Sur (Pozuelo de Alarcón, Madrid, España). Coloquios de Paleontología $51,69-86$

Luz, B., Cormie, A.B., Schwarcz, H.P., 1990. Oxygen isotope variations in phosphate of deer bones. Geochimica et Cosmochimica Acta 54, 1723-1728.

MacFadden, B.J., Cerling, T.E., Prado, J., 1996. Cenozoic terrestrial ecosystem evolution in Argentina: evidence from carbon isotopes of fossil mammal. Palaios 11, 319-327.

MacFadden, B.J., Wang, Y., Cerling, T.E., Anaya, F., 1994. South American fossil mammals and carbon isotopes: a 25 million-year sequence from the Bolivian Andes. Palaeogeography, Palaeoclimatology, Palaeoecology 107, 257-268.

Martin, J.E., Patrick, D., Kihm, A.J., Foit, F.F., Grandstaff, D.E., 2005. Lithostratigraphy, tephrochronology, and rare earth element geochemistry of fossils at the classical Pleistocene fossil lake area, South Central Oregon. Journal of Geology 113, 139-155.

Megías, A.G., Ordóñez, S., Calvo, J.P. 1980. Rupturas sedimentarias en series continentales. Aplicación a la cuenca de Madrid. IX Congreso Nacional de Sedimentología, Salamanca, voL 2, pp. 666-680.

Metzger, C.A., Terry Jr., D.O., Grandstaff, D.E., 2004. Effect of palesol formation on rare earth element signatures in fossil bone. Geology 32, 497-500.

Michel, V., Ildefonse, P., Morin, G., 1995. Chemical and structural changes in Cervus elaphus tooth enamels during fossilization (Lazaret Cave): a combined IR and XRD Rietveld analysis. Applied Geochemistry 10, 145-159.

Miller, K.G., Katz, M.E., 1987. Oligocene to Miocene Benthic Foraminiferal and Abyssal Circulation Changes in the North Atlantic. Micropaleontology 33, 97-149.

Mínguez-Gandú, D., 2000. Marco estratigráfico y sedimentológico de los yacimientos paleontológicos miocenos de Somosaguas (Madrid, España). Coloquios de Paleontología 51, 235-266.

Montes, M., Beamud, B., Garcés, M., Calvo, J.P., 2006. Magnetoestratigrafía de las Unidades Inferior e Intermedia del Mioceno de la Cuenca de Madrid. Revista de la Sociedad Geológica de España 19 (3-4), 281-298.

Nemliher, J.G., Baturin, G.N., Kallaste, T.E., Murdmaa, I.O,, 2004. Transformation of hydroxyapatite of bone phosphate from the ocean bottom during fossilization. Lithology and Mineral Resources 39, 468-479. 
Nriagu, J.O., Moore,P.B., 1984. Phosphates minerals: Their properties and general modes of occurrence. Springer Verlag.

O'Leary, M.H., 1988. Carbon isotopes in photosynthesis. BioScience 38, 328-336.

Pagani, M., Arthur, M.A., Freeman, K.H., 1999. Late Miocene atmospheric $\mathrm{CO}_{2}$ concentrations and the expansion of the $C_{4}$ grass. Science $285,876-878$.

Pagani, M., Arthur, M.A., Freeman, K.H., 2000. Variations in Miocene phytoplankton growth rates in the southwest Atlantic: evidence for changes in ocean circulation. Paleoceanography $15,486-496$.

Palmqvist, P., Gröcke, D.R., Arribas, A., Fariña, R.A., 2003. Paleoecological reconstruction of a lower Pleistocene large mammal community using biogeochemical $\left(\delta^{13} \mathrm{C}, \delta^{15} \mathrm{~N}\right.$, $\left.{ }^{12} \mathrm{O}, \mathrm{Sr}: \mathrm{Zn}\right)$ and ecomorphological approaches. Paleobiology 29, 205-229.

Pascual, R., Ortiz-Jaureguizar, E., 1990. Evolving climates and mammal faunas in Cenozoic South America. Journal of Human Evolution 19, 23-60.

Passey, B.H., Robinson, T.F., Ayliffe, L.K., Cerling, T.E., Sponheimer, M., Dearing, M.D., Roeder, B.L., Ehleringer, J.R., 2005. Carbon isotope fractionation between diet, breath $\mathrm{CO}_{2}$, and bioapatite in different mammals. Journal of Archaeological Science $32,1459-1470$.

Ponel, P., 1995. Rissian, Eemian and Würmian Coleoptera assemblages from La Grande Pile(Vosges, France). Palaeogeography, Palaeoclimatology, Palaeoecology 114, 1-41.

Quade, J., Cerling, T.E., Barry, J.C., Morgan, M.E., Pilbeam, D.R., Chivas, A.R., Lee-Thorp, J.A., van der Menve, N.J., 1992. A 16-Ma record of paleodiet using carbon and oxygen isotopes in fossil teeth from Pakistan. Chemical Geology 94, 183-192.

Quade, J., Cerling, T.E, Andrews, P., Alpagut, B., 1995. Paleodietary reconstruction of Miocene faunas from Pasalar, Turkey using stable carbon and oxygen isotopes of fossil tooth enamel. Journal of Human Evolution 28, 373-384

Quade, J., Solounias, N., Cerling, T.E., 1994. Stable isotopic evidence from paleosol carbonates and fossil teeth in Greece for forest or woodlands over the past $11 \mathrm{Ma}$. Palaeogeography, Palaeoclimatology, Palaeoecology 108, 41-53.

Retallack, G.J., 1992. Middle Miocene fossil plants from FortTenan (Kenya) and evolution of African grasslands. Paleobiology 18, 383-400.

Reynard, B., Lécuyer, C., Grandjean, P., 1999. Crystal-chemical controls on rare earth element concentrations in fossil biogenic apatites and implications for paleoenvironmental reconstructions. Chemical Geology 155, 233-241.

Safont, S., Malgosa, A., Subirà, M.E., Gibert, J., 1998. Can trace elements in fossils provide information about palaeodiet? International Journal of Osteoarchaeology 8, 23-37.

Salesa, M.J., Morales, J., 2000. La fauna de carnívoros del yacimiento aragoniense de Somosaguas (Pozuelo de Alarcón, Madrid). Coloquios de Paleontología 51, 213-222.

Salesa, M.J., Sánchez, LM., 2000. Estudio de los restos de Anchitherium Meyer, 1834 (Equidae; Perissodactyla) del yacimiento de Somosaguas (Pozuelo de Alarcón, Madrid). Coloquios de Paleontología 51, 197-212.

Sánchez, LM., 2000. Rumiantes Mammalia, Artiodactyla delyacimiento de Somosaguas Aragoniense Medio, Madrid, España. Coloquios de Paleontología 51, 223-234.

Sánchez, LM., Salesa, M.J., Morales, J., 1998. Revisión sistemática del género Anchitherium Meyer 1834 (Equidae: Perissodactyla) en España. Estudios Geológicos 54, 39-63.

Sarnthein, M., Thiede, J., Pflaumann, U., Erlenkeuer, H., Fütterer, D., Koopman, B., Lange, H., Seibold, E., 1982. Atmospheric and oceanic circulation patterns off Northwest Africa during the past 25 million years. In: von Rad, U., Hinz, K., Sarthein, M. Seibold, E. (Eds.), Geology of the Northwest African Continental Margin. Springer, Berlin, pp. 547-604.

Schultz, J., 2005. The ecozones of the World. Springer Verlag, Berlin

Shackleton, N.J., Kennett, J.P., 1975. Paleotemperature history of the Cenozoic and the initiation of Antarctic glaciation: oxygen and carbon isotopic analyses in DSDP Sites 277, 279 and 281. Initial Reports of Deep Sea Drilling Project 29, 743-755.

Shevenell, A.E., Kennett, J.P., Iea, D.W., 2004. Middle Miocene Southern Ocean cooling and Antarctic cryosphere expansion. Science 305, 1766-1770.

Sillen, A., 1986. Biogenic and diagenetic $\mathrm{Sr} / \mathrm{Ca}$ in Plio-Pleistocene fossils of the Omo Shungura Formation. Paleobiology 12, 311-323.

Sillen, A., 1992. Strontium-calcium ratios ( $\mathrm{Sr} / \mathrm{Ca}$ ) of Australopithecus robustus and associated fauna from Swartkrans. Journal of Human Evolution 23, 495-516.

Sinclair, A.R.E., 2000. Adaptation, niche partitioning, and coexistence of African bovidae: clues to the past. In: Vrba, E.S., Schaller, G.B. (Eds.), Antelopes, deer, and relatives. Yale University Press, New Haven, pp. 247-260.

Sips, A.J.A.M., Barto, R., Netelenbos, J.C., van der Vijgh, W.J.F., 1997. Preclinical screening of the applicability of strontium as a marker for intestinal calcium absorption. American Journal of Physiology: Endocrinology and Metabolism 272, E422-E428.

Soria, M.D., Amezua, L., Daams, R., Fraile, S., Herráez, E., Morales, J., Nieto, M., PeláezCampomanes, P., Salesa, M.J., Sánchez, I.M., 2000. Faunas del Mioceno. In: Morales, J.
(Coord.), Patrimonio paleontológico de la Comunidad de Madrid. Consejería de Educación de la Comunidad de Madrid, pp. 111-129.

Sponheimer, M., Lee-Thorp, J.A., 1999. The alteration of enamel carbonate environments during fossilisation. Journal of Archaeological Science 26, 143-150.

Sponheimer, M., Lee-Thorp, J.A., 2001. The oxygen isotope composition of mammalian enamel carbonate from Morea Estate, South Africa. Oecologia 126, 153-157.

Sponheimer, M., Lee-Thorp, J.A., 2006. Enamel diagenesis at South African Australopith sites: implications for paleoecological reconstruction with trace elements. Geochimica et Cosmochimica Acta 70, 1644-1654

Sponheimer, M., de Ruiter, D., Lee-Thorp, J.A., Späth, A., 2005. Sr/Ca and early hominin diets revisited: new data from modern and fossil tooth enamel. Journal of Human Evolution 48, 147-156.

Stein, R., Robert, C., 1986. Siliciclastic sediments at sites 588, 590, and 591; Neogene and Paleogene evolution in the Southwest Pacific and Australian climate. Initial Reports of Deep Sea Drilling Project 90, 1437-1455.

Straight, W.H., Barrick, R.E., Eberth, D.A., 2004. Reflections of surface water, seasonality and climate in stable oxygen isotopes from tyrannosaurid tooth enamel Palaeogeography, Palaeoclimatology, Palaeoecology 206, 239-256.

Taylor, S.R., McLennan, S.M., 1985. The continental crust: its composition and evolution. Blackwell, Oxford.

Trueman, CN., 1999. Rare earth element geochemistry and taphonomy of terrestria vertebrate assemblages. Palaios 14, 555-568.

Trueman, CN., Behrensmeyer, A.K., Potts, R., Tuross, N., 2006. High-resolution records of location and stratigraphic provenance from the rare earth element composition of fossil bones. Geochimica et Cosmochimica Acta 70, 4343-4355

Tïtken, T., Vennemann, T.W., Janz, H., Heizmann, E.P.J., 2006. Palaeoenvironment and palaeoclimate of the Middle Miocene lake in the Steinheim basin, SW Germany: a reconstruction from $\mathrm{C}, \mathrm{O}$, and $\mathrm{Sr}$ isotopes of fossil remains. Palaeogeography, Palaeoclimatology, Palaeoecology 241, 457-491.

Tütken, T., Furrer, H., Vennemann, T.W., 2007. Stable isotope compositions of mammoth teeth from Niederweningen, Switzerland: implications for the late Pleistocene climate, environment, and diet. Quaternary International 164-165, 139-150.

van der Made, J., Salesa, M.J., 2004. Early remains of the pig Conohyus simorrensis from the Middle Aragonian of Somosaguas near Madrid-its dispersal into Europe and evolution. Neues Jahrbuch für Geologie und Paläontologie - Abhandlungen 233, 153-168.

van der Meulen, A.J., Daams, R., 1992. Evolution of Early-Middle Miocene rodent faunas in relation to long-term palaeoenvironmental changes. Palaeogeography, Palaeoclimatology, Palaeoecology 93, 227-253.

Vennemann, T.W., Hegner, E., 1998. Oxygen, strontium, and neodymium isotope composition of fossil shark teeth as a proxy for the palaeoceanography and palaeoclimatology of the Miocene northern Alpine Paratethys. Palaeogeography, Palaeoclimatology, Palaeoecology 142, 107-121.

Vennemann, T.W., Fricke, H.C., Blake, R.E., O'Neil, J.R., Colman, A., 2002. Oxygen isotope analysis of phosphates: a comparison of techniques for analysis of $\mathrm{Ag}_{3} \mathrm{PO}_{4}$. Chemical Geology 185, 321-336.

Walter, H., Breckle, S.-Wl., 1986. Ecological systems of the Geobiosphere, 2: tropical and subtropical zonobiomes. Springer Verlag, Berlin

Wang, Y., Deng, T., Biasatti, D.M., 2006. Ancient diets indicate significant uplift of southern Tibet after ca. 7 Ma. Geology 34, 309-312.

Williams, R.A.D., Elliot, J.C., 1979. Basic Applied Dental Biochemistry. Churchill, Livingstone.

Wolfe, J.A., 1985. Distribution of major vegetational types during the Tertiary Geophysical Monograph 32, 357-375

Woodruff, F., Savin, S.M., 1991. Mid-Miocene isotope stratigraphy in the deep sea: high resolution correlations, paleoclimatic cycles, and sediment preservation. Paleoceanography $6,755-806$.

Yurtsever, M., Gat, J.R., 1981. Stable isotope hidrology: deuterieum and oxygen-18 in the water cycle. Atmospheric waters. IAEA Technical Reports Series, voL 210, pp. 103-142

Zachos, J., Pagani, M., Sloan, L., Thomas, E., Billups, K., 2001. Trends, rhythms, and aberrations in global climate 65 Ma to present. Science 292, 686-693.

Zazzo, A., Lécuyer, C., Sheppard, S.M.F., Grandjean, P., Mariotti, A., 2004. Diagenesis and the reconstruction of paleoenvironments: a method to restore original $\delta^{12} \mathrm{O}$ values of carbonate and phosphate from fossil tooth enamel. Geochimica et Cosmochimica Acta 68, 2245-2258. 